WSRC-RP- $-92-859$

DE93 006792

\title{
EMT
}

Equipment and Materials

Technology Department

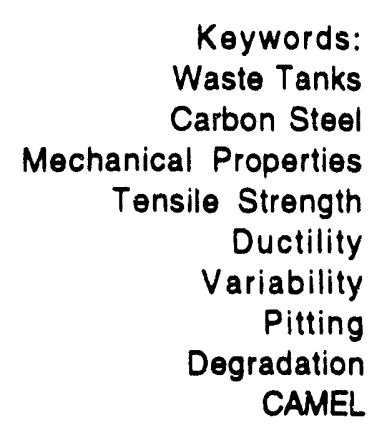

Retention - Permanient

\section{FAILURE STRAIN AND MECHANICAL PROPERTY DATA FOR THE TYPE IIIA WASTE TANK LINERS (U)}

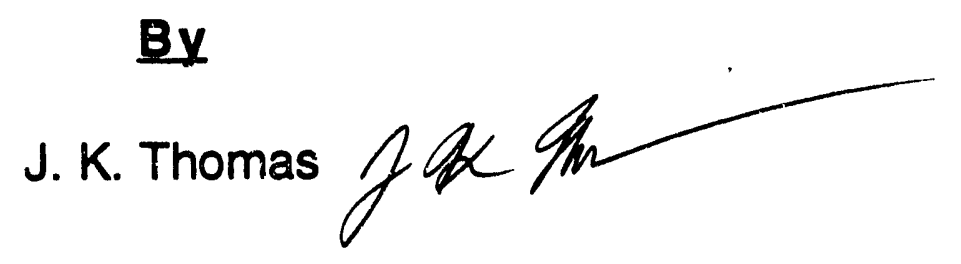

ISSUED: June 1992

$$
\frac{G \cdot C . \text { Go } 7-7-92}{\text { Derivative Classifier }}
$$

SRTC SAVANNAH RIVER TECHNOLOGY CENTER, AIKEN, SC 29808

Westinghouse Savannah River Company

Prepared for the U. S. Department of Energy under Contract DE-AC09-89SR18035 
PROJECT: Failure Strain Criteria for the Type III ITP Waste Tanks

DOCUMENT: WSRC-RP-92-859

TITLE: $\quad$ Failure Strain and Mechanical Property Data for The Type IIIA Waste Tank Liners (U)

TASK: $\quad 92-054-1$

APPROVALS

ar? Penpleaty

W.L. Datghgfrty, TECHNICAL REVIEWER MATERIALS TECHNOLOGY

N.G. Aurdalle

N. G. Awadalla, MANAGER

MATERIALS TECHNOLOGY

D. T. Rankien for

T. L. Capeletti, MANAGER

MATERIALS TECHNOLOGY

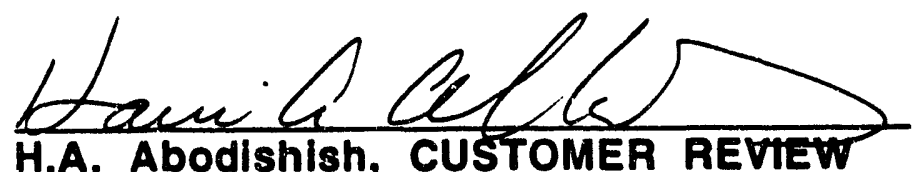

WASTE MANAGEMENT DIVISION

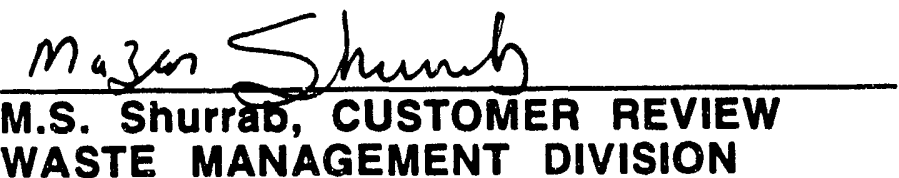

DATE: I July 92

DATE: July 14,1992

DATE: $2 / 14 / 92$ DATE: July 9, 1942 


\section{EXECUTIVE SUMMARY}

The SRS Waste Tanks to be employed in the In-Tank Precipitation (ITP) process are undergoing a structural evaluation in order to define their response to a hypothetical deflagration accident. At the request of the Waste Management Division, a task was initiated to 1) provide mechanical property data to support the structural analyses, and 2) characterize the impact of mechanical property variability and materials degradation on the failure strain of the primary liner.

Stress-strain curves are provided for A537 Class 1 and A516 Grade 70 carbon steels, the materials employed to construct the primary and secondary liners of the waste tanks of interest. These curves were constructed using the mill certification data for the plates employed to construct the tanks, data from tests conducted at SRS with these steels, typical data from manufacturers, and applicable literature data. The data were adjusted to account for the effects of strain rate and temperature. The stress at failure was also adjusted for necking.

The stress-strain curves given in this report were constructed using a conservative set of tensile data. The stress-strain data employed in the structural analyses were based upon these curves, and are therefore also conservative with respect to mechanical property variability. Although some plates will have strengths below those employed in the structural model, prior analyses indicate that this will have a negligible effect on failure pressure.

Sufficient chemistry and temperature controls are in place to ensure that the contents of the waste tanks do not significantly degrade the primary liner; this conclusion is supported by the available inspection data. The only significant degradation of the primary liner which has occurred is pitting of the bottom plates, which occurred during the construction phase. These pits are not expected to lead to stress corrosion cracking of the bottom plates during normal operation even if the chemistry control requirements were violated. Reduced uniform strain values for use with the failure criterion are provided to account for the effects of pitting.

A knockdown factor (factor of safety), $\mathrm{K}_{3}$, of 1.05 on the primary liner failure strain to account for the effects of mechanical property variability and materials degradation is recommended. This value is judged to be conservative. 


\section{TABLE OF CONTENTS}

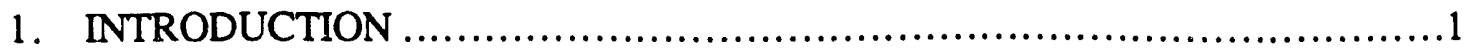

2. STRESS-STRAIN CURVES FOR LINERS .................................2

2.1 Primary Liner (ASTM A537 Class 1 Carbon Steel) .........................

2.1.1 ASTM Specifications..........................................

2.1.2 Typical Manufacturer Tensile Property Data ..........................3

2.1.3 Mill Certification Data from Tanks 48 through $51 . \ldots . \ldots \ldots \ldots \ldots \ldots . . . . . .4$

2.1.4 Additional Tensile Property Data .................................6

2.1.5 Recommended Tensile Properties (Engineering Formulation) .........6

2.1.6 Effect of Fabrication Processes and Post-Fabrication Annealing .......7

2.1.7 Effect of Temperature ...........................................

2.1.8 Effect of Strain Rate.............................................8

2.1.9 Adjusted Tensile Properties (Engineering Formulation) ..............9

2.1.10 Recommended Tensile Properties (True Formulation)..............9

2.2 Secondary Liner (ASTM A516 Grade 70 Carbon Steel)...........................11

2.2.1 ASTM Specifications............................................11

2.2.2 Mill Certification Data from Tanks 48 through $51 . \ldots \ldots \ldots \ldots \ldots \ldots . . . \ldots 12$

2.2.3 Additional Tensile Property Data ..................................12

2.2.4 Recommended Tensile Properties (Engineering Formulation) .........13

2.2.5 Adjustments to the Recommended Tensile Properties.....................14

2.2.6 Recommended Tensile Properties (True Formulation)................14

3. PRIMARY LINER FAIIUURE STRAIN ................................... 15

3.1 Effect of Mechanical Property Variability........................................15

3.2 Effect of Material Degradation ............................................ 16

3.3 Net Adjustment to Primary Liner Failure Strain ........................... 19

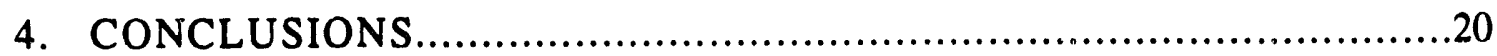

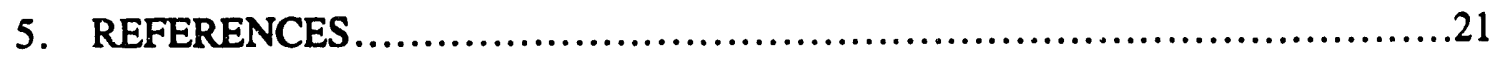




\section{LIST OF TABLES}

1 Tensile Property and Chemical Composition Requirements for ASTM A537 Class 1 and A516 Grade 70 Carbon Steels...........................................24

2 Actual vs. Min. Properties for Lukens LT-75N Steel Plate........................ 25

3 Actual vs. Min. Properties for Armco LO-TEMP Steel Plate......................25

4 A537 Class 1 Plates Employed to Construct Tanks 48 - 51 (All Plates)................26

5 A537 Class 1 Plates Employed to Construct Tanks 48 - 51 (1/2" Plates)............27

6 Tensile Property Summary for Plates Employed to Construct Tanks 48 - 51..........28

7 Results From MTS A537 Class 1 CERT Tests.....................................28

8 A537 Class 1 Nominal and Adjusted Tensile Properties (Eng. Formulation)..........29

9 Recommended Property Data for A537 Class 1 Steel (Primary Liner). ..............29

10 A516 Grade 70 Plates Employed to Construct Tanks 48 - 51.................... 30

11 Recommended Property Data for A516 Grade 70 Steel (Secondary Liner).......... 30

12 Uniform Strain Values Considering Effect of Pitting. ........................... 31

\section{LIST OF FIGURES}

1 Distribution of A537 Class 1 Mill Certification Yield Strength Data..................32

2 Distribution of A537 Class 1 Mill Certification Tensile Strength Data...............33

3 Total Elongation and Yield vs. Tensile Strength for A537 Class 1 Plates.............34

4 Distribution of 1/2" A537 Class 1 Mill Certification Yield Strength Data. ............35

5 Distribution of 1/2" A537 Class 1 Mill Certification Tensile Strength Data...........36

6 Total Elongation and Yield vs. Tensile Strength for 1/2" A537 Class 1 Plates........37

7 Recommended A537 Class 1 Stress-Strain Curve at $125^{\circ} \mathrm{C}$ and $0.2 \mathrm{sec}^{-1} \ldots \ldots \ldots . . . .38$

8 Distribution of A516 Grade 70 Mill Certification Yield Strength Data................39

9 Distribution of A516 Grade 70 Mill Certification Tensile Strength Data.................40

10 Total Elongation and Yield vs. Tensile Strength for A516 Grade 70 Plates.............41

11 Recommended A516 Grade 70 Stress-Strain Curve at $0.2 \mathrm{sec}^{-1} \ldots \ldots \ldots \ldots \ldots \ldots \ldots . . .42$ 


\section{INTRODUCTION}

The SRS waste tanks to be employed for In-Tank Precipitation (ITP) to prepare feed for the DWPF are undergoing a structural evaluation in order to define their response to a hypothetical deflagration accident. At the request of the Waste Management Division, a task was initiated by the Materials Technology Section (MTS) to 1, , rovide mechanical property data to support the structural analyses of the waste tanks, and 2) characterize the impact of mechanical property variability and materials degradation on the failure strain of the primary liner (Thomas 1992a).

The waste tanks of interest in this evaluation are numbers 48,49 , and 50; these tanks are of the Type IIIA design class (SRS 1991). The Type IIIA primary liner is constructed of ASTM A537 Class 1 carbon steel, and the secondary liner is constructed of ASTM A516 Grade 70 carbon steel.

Section 2 of this report presents the development of the stress-strain curves for the primary and secondary liner; these curves were generated in order to support the structural analysis of the waste tank. Section 3 presents the evaluation of the impact of mechanical property variability and materials degradation on the failure strain of the primary liner. The conclusions of this evaluation are given in Section 4. 
plates employed to construct the primary liners were examined and a limited amount of additional manufacturer data were obtained. The results of the evaluation presented in this report supersede those given in the preliminary evaluation; as discussed in Section 2.1.10, the values given in the preliminary evaluation are conservative.

\subsubsection{ASTM Specifications}

Table 1 gives the tensile property and chemical composition requirements for ASTM A537 Class 1 carbon steel. The total elongation over an 8 " gauge length is slightly smaller than that for a 2 " gauge length since necking makes a smaller contribution to the total elongation at failure. Note that total elongation cannot be used directly in the construction of a true stress - true strain curve. Furthermore, total elongation is sensitive to specimen geometry and it is therefore difficult to compare values from different sources unless specimen geometry is specified. Total elongation is usually employed as a measure of ductility in comparing steels and provides information on the consistency of a manufacturing process. It is included in this evaluation for the sake of completeness.

In addition to the tensile properties given in Table 1, the following values are applicable to this steel (Brockenbrough and Johnston 1968, Mindlin and Ho 1990):

Density: $\quad 0.284 \mathrm{lb} / \mathrm{in}^{3}$

Young's Modulus: 28 to $30 \times 10^{6} \mathrm{psi}$

Poisson's Ratio: $\quad 0.30$ to 0.33

\subsubsection{Typical Manufacturer Tensile Property Data}

Several commercial steels were identified which meet the A537 Class 1 standard: U.S. Steel CHAR-PAC (Brockenbrough and Johnston 1968, Alloy Digest 1967a, USS 1982), Armco LO-TEMP (Mindlin and Ho 1990), Bethlehem RQC-60N (Alloy Digest 1971 and Bethlehem 1977), and Lukens LT-75N (Alloy Digest 1967b).

The properties given in Table 1 are the minimum values required by the ASTM standard, as opposed to typical values obtained frem plate testing. Table 2 gives typical data for plates fabricated from the Lukens LT-75N steel (Alloy Digest 1967b); as discussed above, tensile properties vary with plate thickness as a result of cooling rate differences. For a 1/2" plate, the yield and tensile strengths are 5.4 and $9.0 \mathrm{ksi}$ above the minimum specified values. The total elongation over an 8 " gauge length is $7 \%$ larger than the minimum value specified 


\section{STRESS-STRAIN CURVES FOR LINERS}

True stress - true strain curves for the primary and secondary liners of the Type IIIA waste tanks were developed as part of this task in order to support the waste tank structural analysis. The primary and secondary liners are constructed of ASTM A537 Class 1 and A516 Grade 70 carbon steel plates. This section presents the tensile data employed, the methodology employed to analyze these data, and the resulting stress-strain curves.

\subsection{Primary Liner (ASTM A537 Class 1 Carbon Steel)}

The primary liner is constructed of A537 Class 1 steel, which is a heat-treated, highstrength, killed, carbon-manganese-silicon steel. The heat treatment for this steel consists of normalizing at $1625-1675^{\circ} \mathrm{F}\left(885-913^{\circ} \mathrm{C}\right)$ for a duration of 1 hour per inch of plate thickness followed by air cooling. Normalization differs from full annealing in that the cooling rate is more rapid; both strength and ductility are increased relative to full annealing (Rollason 1973). The liner was stress relieved after the tank was constructed by heating to $1100^{\circ} \mathrm{F}$ for at least 1 hour.

The thickness of the primary liner bottom is $1 / 2$ inch. The plates comprising the inner knuckle are 5/8" thick; this thickness extends inward 3' from the tank inner annulus and to a height of $12^{\prime}$ along the annulus. The outer knuckle is constructed of $7 / 8$ " thick plate; this thickness extends inward $4^{\prime}$ along the liner bottom and to a height of $6^{\prime}$ along the tank wall. The next $10^{\prime}$ of the primary liner is comprised of $5^{\prime}$ sections of $3 / 4 "$ and $5 / 8^{\prime \prime}$ plates. The remainder of the primary liner (e.g. the upper half) is made of 1/2" plates (SRS 1978a).

The properties of this steel vary with plate thickness as a result of cooling rate differences. The highest primary liner strains for a hydrogen deflagration accident in the Type III waste tanks would be expected to occur in the upper sidewall section, since this section is constructed of the thinnest plates (1/2") and has the least restraint. A preliminary structural analysis of the response of the Type III waste tanks showed that this was the location of maximum strain (Gong 1991). The main emphasis in this evaluation is therefore placed on the properties of $1 / 2$ " thick plate.

A preliminary evaluation of the tensile properties of and stress-strain curve for the primary liner was given in Thomas (1992c) and was employed in the structural analysis of the waste tanks. Subsequent to the preliminary evaluation, the mill certification data for the 
by Lukens; note that the minimum value specified by Lukens is $2 \%$ larger than the ASTM standard requirement ( $20 \%$ vs. $18 \%$ ).

Table 3 gives typical data for plates fabricated from the Armco LO-TEMP steel (Mindlin and Ho 1990). For a 1/2" thick plate, the yield and tensile strengths are 8.6 and $10.3 \mathrm{ksi}$ above the minimum specified values, respectively, and the total elongation over a 2 " gauge length is $6 \%$ larger than the specified minimum value. Typical reduction in area values for a 1" ihick plate of this steel are $65-68 \%$ with a corresponding total elongation of approximately 28\% (Mindlin and Ho 1990). A typical stress=strain curve for an ASTM standard 1/2" diameter specimen made from 1 " thick LO-TEMP plate gives yield and tensile strengths of approximately 57 and $80 \mathrm{ksi}$, with uniform and total elongations of 16 and 32\% (Thomas 1992b).

For the RQC-60N steel, a typical stress-strain curve for an ASTM standard 1/2" diameter specimen made from 1 " thick plate gives yield and tensile strengths of approximately 51 and $83 \mathrm{ksi}$, with uniform and total elongations of 10 and $28 \%$ and a reduction in area of 67.5\% (Bethlehem 1977).

\subsubsection{Mill Certification Data from Tanks 48 through 51}

The mill certification test reports for the plates employed to construct the primary liners of waste tanks 48-51 were examined as part of this evaluation; the test reports give the measured yield strength, tensile strength, total elongation over an 8 " gauge length, and heat chemical composition. The yield strength values given in the mill certification test reports were measured using the $0.5 \%$ extension-under-load (EUL) method, and thus should correspond to the lower yield point. For carbon steels, the yield as measured by $0.5 \%$ EUL is roughly equivalent to that measured by the $0.2 \%$ offset method (Brockenbrough and Johnston 1968).

Table 4 summarizes the data taken from all of the mill certification test reports for the primary liner (294 data sets); a compilation of this data is retained in the task files. The tensile properties and composition meet the A537 Class 1 requirements. Figures 1 and 2 show the distribution of the yield and tensile strength data; to construct these distributions, the data were collected in $1 \mathrm{ksi}$ bins (e.g. the $56 \mathrm{ksi}$ yield strength column shown in Figure 1 incorporates yield strengths $\geq 55.5 \mathrm{ksi}$ and $<56.5 \mathrm{ksi}$ ). Also shown in these figures is the normal, or Gaussian, distribution (Tsoulfanidis 1983) generated using the average 
value and standard deviation values given in Table 4. The normal distribution value was calculated at the mid-point of the bin and multiplied by the bin width $(1 \mathrm{ksi})$, as shown below:

$$
\mathrm{G}\left(\mathrm{x}_{\mathrm{m}}\right)=\frac{\exp \left(-\frac{\left(\mathrm{x}_{\mathrm{m}}-\mathrm{x}_{\mathrm{a}}\right)^{2}}{2 \sigma^{2}}\right)}{\sqrt{2 \pi} \sigma}(\Delta \mathrm{x})
$$

where: $G\left(x_{m}\right)=$ Normal distribution value assigned to mid-point of bin,

$$
x_{m}=\text { Mid-point of bin (ksi), }
$$

$\mathrm{x}_{\mathrm{a}} \quad=$ Average value of the data set,

$\sigma \quad=$ Absolute standard deviation of the data set, and

$\Delta \mathbf{x} \quad=$ Bin width (1 ksi).

As can be seen in Figures 1 and 2, these data are adequately described by a normal distribution. Figure 3 illustrates the relationship between tensile strength and total elongation, and tensile strength and yield strength. As expected, total elongation decreases slightly with ir reasing tensile strength, and yield strength increases with tensile strength. The linear fits slown in figure 3 are intended as "eye guides" only; there is considerable scatter in the data and they show only a weak correlation.

The mill certification test reports for the $1 / 2$ " thick plate were of particular interest since, as discussed previously, the location of maximum predicted primary liner strain corresponds to the portion of the liner constructed of $1 / 2$ " thick plate. Table 5 summarizes the data taken from the mill certification test reports for 1/2" thick A537 Class 1 plates (174 data sets). Figures 5 and 6 show the distribution of the yield and tensile strength data, along with the normal distributions generated using eqn.(1); these data are also adequately described with a normal distribution. Figure 7 illustrates the relationship between tensile strength and total elongation, and tensile strength and yield strength; the trends for the $1 / 2$ " thick plates are the same as those shown in Figure 3.

Table 6 summarizes the tensile property data taken from the mill certification test reports for the primary liner plates [the data for the secondary liner (A516 Grade 70) are also given]. The minimum values are above the ASTM A537 Class 1 requirements, and the average values are well above the nyired values. For the purposes of constructing a stress-strain curve for input to the waste tank structural analysis, the average value minus two standard deviations is judged to give an acceptable degree of conservativism. The "average - $2 \sigma$ " values given in Tabla 6 for A537 Class 1 are slightly above the minimum values. 


\subsubsection{Additional Tensile Property Data}

The data discussed above and given in Tables 2 through 4 are insufficient to allow the construction of a true stress - true strain curve; uniform elongation, reduction in area, and the stress at failure are also required. As discussed in Section 2.1.1, total elongation is not required to construct the true stress - true strain curve.

Constant extension rate tensile (CERT) tests have been performed with A537 Class 1 steel by the SRTC Materials Technology Section in connection with a stress corrosion cracking (SCC) susceptibility study (Wiersma 1992a and 1992b). These tests were conducted on tensile specimens with a $1^{\prime \prime}$ gauge length and $0.25^{\prime \prime}$ diameter in air at room temperature ( $20-30^{\circ} \mathrm{C}$ ) and in simulated waste solutions at $60^{\circ} \mathrm{C}$. The cross head speed was set to give a strain rate of $5 \times 10^{-4} \mathrm{sec}^{-1}$ in the air tests, and $1 \times 10^{-6} \mathrm{sec}^{-1}$ in the waste solution tests. Data from tests in solutions showing indications of SCC were not employed here, and the data for the remainder of the solutions were averaged (the property data for these solutions were all very similar). Table 7 gives the resulting data. Both strength and ductility are higher for the test in ain, which employed a higher strain rate and lower temperature.

Correlations between tensile strength and ductility measures for carbon steels can also be employed to provide estirnates of the required data. For a tensile strength of $75 \mathrm{ksi}$, the correlations given by Gross (1964) give uniform and total elongations of 18 and $28 \%$ and a reduction in area of $64 \%$. These values are in reasonable agreement with those from the CERT tests discussed above.

\subsubsection{Recommended Tensile Properties (Engineering Formulation)}

The data discussed in Sections 2.1.1 through 2.1.4 were employed to form the recommended tensile properties given in Table 8 (column labeled "nominal value"). The yield and tensile strengths are taken to be the average minus two standard deviation values

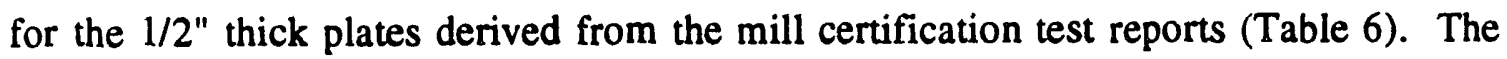
uniform elongation value is based on the correlation with tensile strength and the MTS CERT test data. The stress at failure value is based on the MTS CERT test data. The total elongation and reduction in area values are based on typical data reported by the manufacturers, the correlation with tensile strength, and the MTS CERT test data. Total elongation value is included only for the sake of completeness. 


\subsubsection{Effect of Fabrication Processes and Post-Fabrication Annealing}

The plates employed to construct the primary liner were cold-worked as a result of rolling and forming operations during tank construction. After tank construction was complete, the liner was stress relieved by heating to $1100^{\circ} \mathrm{F}\left(621^{\circ} \mathrm{C}\right)$ for at least 1 hour (SRS $1978 \mathrm{~b}$ and Jenkins 1980); this stress relief treatment is consistent with the manufacturer recommendations for this steel (Alloy Digest 1967a, 1967b, and 1971, Bethlehem 1977, USS 1982, Mindlin and Ho 1990). The data given in Mindlin and Ho (1990) show that Armco LO-TEMP steel strained to $3 \%$ and stress relieved at $1100^{\circ} \mathrm{F}$ would have a yield and tensile strength increases of approximately 6 and $2 \mathrm{ksi}$, respectively, and a total elongation decrease of approximately $1 \%$. The plates in the waste tank expected to accumulate the highest strain during a hydrogen defla ${ }_{1}$ ation accident (e.g. the 1/2" thick upper sidewall plates) would have been subjected to $3 \%$ less than $3 \%$ during fabrication and hence the change in properties would be less. In this analysis, it is assumed that no increase in strength or reduction in ductility would occur as a result of fabrication processes.

The yield stress employed for LWR containment vessel analyses has been set to $10 \%$ below the value obtained in uniaxial tensile tests to account for the Bauschinger effect and strain rate effects (Clauss et al. 1987 and Miller 1990). In this case, the Bauschinger Effect refers to a reduction in the yield point upon tensile loading after prior compression; only the yield point is effected and the strength reduction is only evident up to a few percent strain. However, the stress relief treatment employed with the waste tanks would be expected to partially anneal the cold work introduced during fabrication. In this analysis, it is assumed that no decrease in the yield strength would occur as a result of the Bauschinger effect. Strain rate effects are discussed in a following section and, at the temperatures and strain rates of interest in this analysis, serve to increase the yield stress.

\subsubsection{Effect of Temperature}

The mechanical property data discussed above were generated in iests under ambient conditions, with the exception of the MTS CERT tests in simulated waste solutions which were run at $60^{\circ} \mathrm{C}$ (Table 5). During operation, the temperature of the primary liner would be less than approximately $100^{\circ} \mathrm{C}$ (SRS 1977). The temperature of the gas inside the waste tank would be expected to rise significantly during a hydrogen deflagration event. However, the primary liner deformation is accumulated over a short period (less than 1 
second). Considering the thermal inertia of the carbon steel liner (e.g. low thermal conductivity, high specific heat, and large mass), the heat transferred to the liner and its corresponding temper ture rise would be very small during deformation. Based on a simplified calculation of the energy generated within the liner itself due to the plastic deformation, the liner temperature rise due to deformation would be less than $25^{\circ} \mathrm{C}$. The maximum liner temperature during deformation would therefore be $125^{\circ} \mathrm{C}$. Data on the effects of tempe:atur on tensile properties are given in Miller and Heger (1950), Simmons and Cross (1955), Brockenbrough and Johnston (1968), the Nuclear Systems Materials Handbook (1987), and Mindlin and Ho (1990). In general, both strength and ductility are decreased at $125^{\circ} \mathrm{C}$ relative to the ambient temperature $\left(20-30^{\circ} \mathrm{C}\right)$ values. Temperature correction fastors, defined here as the ratio of a property at the temperatur: if interest $\left(125^{\circ} \mathrm{C}\right)$ to that at ambient temperature [e.g. $\mathrm{p}\left(125^{\circ} \mathrm{C}\right) / \mathrm{p}\left(20^{\circ} \mathrm{C}\right)$ - where ' $\mathrm{p}$ ' is the, roperty of interest], were estimated from the data given in these references and are listed in Table 8. As can be seen in Table 8, the maximum shange from the ambient temperature property value is $15 \%$. Poisson's Ratio is assumed to be temperature independent.

\subsubsection{Effect of Strain Rate}

Conventional tensile tests are conducted with strain rates on the order of $0.005-0.05 \mathrm{~min}^{-1}$ $\left(8 \times 10^{-4}\right.$ to $8 \times 10^{-5} \mathrm{sec}^{-1}$ ) (ASTM Standards E21-79 and E8-90). The mechanical property data discussed above were generated with strain rates in or very near this range, with the exception of the MTS CERT tests in simulated waste solutions which were run at $1 \times 10^{-6}$ $\sec ^{-1}$ (Table 7). In this evaluation, it is assumed that the peak pressure due to a deflagration accident would occur within 1 second. Wallace and Yau (1986) report that the pressure peak would be reached within a few m:lliseconds, although no supporting analysis is provided. A 1 second duration to reach the maximum internal tank pressure gives an average liner strain rate of approximately $12 \mathrm{~min}^{-1}$ at the locations of highest strain $(\varepsilon \approx$ $20 \%, \Delta t \approx 1 \mathrm{sec}, \varepsilon / \Delta t=0.2 \mathrm{sec}^{-1} \approx 12 \mathrm{~min}^{-1}$ ), roughly 3 orders of magnitude above that for a normal tensile test. This increase in strain rate is sufficient to have a significant impact on mechanical properties. Data on the effects of strain rate on tensile properties are given in Brockenbrough and Johnston (1968), Voorhees (1969), and the Nuclear Systems Materials Handbook (1987). For carbon steels at temperatures up to the maximum value of interest in this analysis, increased strain rate results in increased strength without a significant impact on ductility. Strain rate correction factors, defined in an analogous fashion to the ieńperăaiuí côtrection facturs discussed above, were estimated from the data given in these references and are listed in Table 8 . The yield and tensile strengths are expected to increase 
by 13 and 7\%, respectively; the stress at failure is assumed to increase by the same amount as the tensile strength (7\%). The ductility properties are assumed to be unaffected by the change in strain rate, and the elastic properties are assumed to be strain rate independent.

The assumed time required to reach the maximum pressure, 1 second, is judged th oe conservative. Shorter times would lead to higher strain rates, and th:refore higher strength values.

\subsubsection{Adjusted Tensile Properties (Engineering Formulation)}

The recommended set of nominal tensile properties was given in Table 8 along with the correction factors for temperature and strain rate discussed in the previous two sections. The last column in Table 8 gives the resulting tensile property set, in engineering formulation, for use in structural analysis of the waste tank under the conditions predicted for a deflagration accident. Note that this steel exhibits yield-point elongation (accumulation of plastic strain under constant stress after yield and prior to the onivet of work-hardening) out to approximately $2 \%$ strain (Brockenbrough and Johnston 1968).

In order to define the stress-strain curve, engineering stress and strain values are given in Table 9 corresponding to yield, initiation of strain hardening (e.g. the end of the yield-point elongation region), onset of necking (e.g. the ultimate strength), and failure.

\subsubsection{Recommended Tensile Properties (True Formulation)}

The first set of tensile properties given in Table 9 are in expressed in terms of the engineering formufation. That is, stress and strain are defined in terms of the initial gauge length and cross section area, as shown below:

$$
\begin{aligned}
& s=P / A_{0} \\
& e=\left(1-l_{0}\right) / l_{0}
\end{aligned}
$$

$$
\text { where: } \begin{array}{ll}
\mathbf{s} & =\text { Engineering stress, } \\
\mathbf{P} & =\text { Applied load, } \\
\mathrm{A}_{0} & =\text { Original cross sectional area, } \\
\mathrm{e} & =\text { Engineering strain, } \\
1 & =\text { Instantaneous length, and } \\
\mathrm{l}_{0} & =\text { Original length. }
\end{array}
$$


For structural analysis involving large plastic deformation, true stress and strain formulations are required. True stress and strain are defined below:

$$
\begin{aligned}
& \sigma=P / A \\
& \varepsilon=\ln \left(1 / l_{0}\right)
\end{aligned}
$$

where: $\sigma=$ True stress,

A = Instantaneous cross sectional area, and

$\varepsilon \quad=$ True strain.

True stress and strain values may be calculated directly from the engineering stress and strain under uniform elongation conditions (e.g. prior to necking) using the expressions given below:

$$
\begin{aligned}
& \varepsilon=\ln (i+e) \\
& \sigma=s(\imath+1)=s \exp (\varepsilon)
\end{aligned}
$$

After necking, reduction in area values are required and the expressionis given below can be used to calculate the true stress and strain values:

$$
\begin{aligned}
& \varepsilon=\ln [1 /(1-\mathrm{RA})] \\
& \sigma=s[1 /(1-\mathrm{RA})]=s \exp (\varepsilon)
\end{aligned}
$$

where: $R A=$ Reduction in area $\left[R A=\left(A_{0}-A\right) / A_{0}\right]$.

Thus, the strain and stress at failure may be calculated from the post-test RA value. The stress in the necked region should be corrected to account for triaxial effects (e.g. the applied stress is partially offset by a non-uniform hydrostatic stress established in the neck). The Bridgman correction factor, which is defined as the effective true axial stress divided by the uncorrected true axial stress, can be used for this purpose. Tegart (1966) and Dieter (1985) provide correlations of the Bridgman correction factor to total true strain and necking strain (total true strain minus uniform true strain), respectively. For the values given above, a Bridgman correction factor of 0.86 is applicable at failure and was employed in this analysis. Note that the necking correction would not be required if the structural model is constructed such that the predicted deformation accounts for the triaxial stress state established after uniform strain is exceeded; if the structural model is not constructed in this fashion, then the values adjusted using the Bridgman correction factor should be employed. 
The resulting irue stress and strain values are given in Table 9 and illustrated in Figure 7 along with the engineering values. Lines have been drawn between the true stress and strain data on Figure 7 to illustrate the application of linear interpolation. Also shown in Figure 7 is a simple power law fit to the data at the beginning of the strain hardening and beginning of necking regions. Either the linear interpolation or power law fit may be employed for structural ialyses. The power law fit is a better description of the actual stress-strain curve. Appication of the linear interpolation would be conservative.

For the purposes of structurai analysis, it may improve numerical stability to eliminate the yield point from the stress-strain curve (e.g. make the curve linear up to the onset of strain hardening). This adjustment would not be expected to have a significant effect on the results of the structural anclysis involving large plastic strains.

With the exception of the yield and tensile strengths, the tensile property values given in Table 9 are the same as those given in the preliminary evaluation (Thomas 1992c). The yield strength value was decreased by $0.1 \mathrm{ksi}$, which will have a negligible effect on the structural analysis. The tensile strength was increased by $3.3 \mathrm{ksi}$, so that analysis performed using the preliminary tensile strength value is conservative.

\subsection{Secondary Liner (ASTM A516 Grade 70 Carbon Steel)}

The secondary liner is constructed of A516 Grade 70 steel, which is a structural carbon steel with good notch toughness intended for use at ambient or lower temperatures. The plates employed to construct the secondary liner were not heat treated and were used in the as-rolled condition (SRS 1978b). The secondary liner is specified to be $3 / 8$ " thick, although the mill certification test reports for the A516 Grade 70 plates included a few plates of 7/16" thickness. The recom.nended tensile data given in this section were supplied prior to the release of this report as input to the waste tank structural analysis (Thomas 1992b).

\subsubsection{ASTM Specifications}

Table 1 gives the tensile property and chemical composition requirements for ASTM A516 Grade 70 carbon steel. The density and elastic properties given in Section 2.1.1 are also applicable to this steel (Brockenbrough and Johnston 1968). 


\subsubsection{Mill Certification Data from Tanks 48 through 51}

The mill certification test reports for the plates employed to construct the secondary liners of waste tanks 48-51 were examined as part of this evaluation. The information contained in these reports was discussed in Section 2.1.3.

Table 10 summarizes the data taken from all of the mill certification test reports for the primary liner (290 data sets); a compilation of these data is retained in the task files. The tensile properties and composition meet the A516 Grade 70 requirements. Figures 8 and 9 show the distribution of the yield and tensile strength data; also shown on these figures is a normal distribution generated using eqn.(1) along with the average value and standard deviation values given in Table 10. As can be seen in Figures 8 and 9, these data are adequately described by a normal distribution. Figure 10 illustrates the relationship between tensile strength and total elongation, and tensile strength and yield strength. As with the A516 Class 1 dats, stal elongation decreases slightly with increasing tensile strength and yield strength increases with tensile strength, although there is considerable scatter in the data and they show only a weak correlation.

The tensile property data taken from the mill certification test reports for the secondary lint plates are summarized in Table 6. The minimum values are above the ASTM A516 Grade 70 requirements, and the average values are well above the required values. For the purposes of constructing a stress-strain curve for input to the waste tank structural analysis, the average value minus two standard deviations is judged to give an acceptable degree of conservativism. The "average - $2 \sigma$ " values given in Table 6 for ASTM A516 Grade 70 are above the code requirements, and the tensile strength is above the minimum value.

\subsubsection{Additional Tensile Property Data}

Peacock (1975) tested A516 Grade 70 tensile specimens as part of an earlier waste tank analysis. He reports average yield and tensile strengths of 52 and $79 \mathrm{ksi}$ for a test set of 3 specimens.

Mindlin and Ho (1990) give data for both ASTM A515 Grade 70 and A212 Grade B carbon steel plates. The property requirement for these steels are essentially identical to those for ASTM A516 Grade 70. The A515 and A516 specifications replaced the A212 
and A201 specifications in 1964. The equivalence between the specifications is as shown below:
A516 Grade $55 \approx$ A201 Grade A
A516 Grade $60 \approx$ A201 Grade B
A516 Grade $65 \approx A 212$ Grade A
A516 Grade $70 \approx A 212$ Grade B

The A515 series has the same property requirements as the A516 series, but has a slightly higher carbon content and is made to a coarse grain practice, whereas A516 is made to a fine grain practice. Data for A212 Grade B and A515 Grade 70 are assumed to be applicable to A516 Grade 70. A stress-strain curve for A212 Grade B in the as-rolled condition presented in Mindlin and Ho (1990) gives yield and tensile strengths of approximately 39 and $72 \mathrm{ksi}$ with a uniform elongation of 26\%. Mindlin and Ho (1990) also present average values for tensile tests conducted in the transverse and longitudinal direction (parallel and perpendicular to the rolling direction, 3 tests for each orientation) for A515 Grade 70 steel in the stress relieved condition $\left(650^{\circ} \mathrm{F}\right.$ for 1 hour). The average values give a yield strength of $45.5 \mathrm{ksi}$, a tensile strength of $70.3 \mathrm{ksi}$, and an RA of $61 \%$. Chow et al. (1963) report a true yield strength of $45 \mathrm{ksi}$, a true stress at failure of $155 \mathrm{ksi}$, and an RA of $66 \%$ for an A212 Grade B tensile specimen.

The correlations between carbon steel tensile strength and ductility measures discussed in Section 2.1.4 are also applicable for the secondary liner. Since the tensile strengths for the primary and secondary liners are essentially identical (see Table 6), the ductility values predicted by these correlations are the same (e.g. uniform elongations $\approx 28 \%$ and $R A \approx$ $64 \%$ ). These values are in reasonable agreement with the data presented above.

\subsubsection{Recommended Tensile Properties (Engineering Formulation)}

The yield and tensile strengths are taken to be the mill certification test report average minus two standard deviation (41.6 and $74.6 \mathrm{ksi}$, respectively). Since the tensile strengths of A516 Grade 70 and A537 Class 1 are approximately equal, the ductility values were assumed to be the same (uniform elongation of $18 \%$ and $\mathrm{RA}$ of $60 \%$ ); the literature values discussed in Section 2.2.3 are in general agreement with these values. The true stress at failure is taken directly from Chow et al. (1963) [e.g. $155 \mathrm{ksi}$ ]; for a reduction in area of $60 \%$ this corresponds to an engineering stress at failure of $62 \mathrm{ksi}$. This steel exhibits yieldpoint elongation (accumulation of plastic strain under constant stress after yield and prior to the onset of work-hardening) out to approximately $1.5 \%$ strain (Brockenbrough and 
Johnston 1968). The nominal values of Young's Modulus and Poisson's Ratio were taken to be $29 \times 10^{3} \mathrm{ksi}$ and 0.33 , respectively, as was the case for the primary liner.

\subsubsection{Adjustments to the Recommended Tensile Properties}

As was the case for the primary liner (Section 2.1.6), it is assumed that no increase in strength or reduction in ductility would occur as a result of fabrication processes. The secondary liner would not be expected to reach temperatures much higher than ambient since air flow is maintained in the annulus between the primary and secondary liners, and the secondary liner is in contact with the concrete surrounding the waste tank; a thermal analyses was not conducted to confirm this assumption. Therefore, adjustments to the secondary liner mechanical properties to account for temperature are not required. The strain rate for the secondary liner in the region of highest strain should be approximately the same as that of the primary liner since the deformation of the secondary liner follows that of the primary. Therefore, the strain rate adjustment factors derived in Section 2.1.8 and given in Table 8 are applied for the secondary liner as well (1.13 for yield strength, and $1.0^{\prime} 7$ for tensile strength and stress at failure). The recommended engireering stress and strain values, adjusted for the effects of strain rate, are given in Table 11.

\subsubsection{Recommended Tensile Properties (True Formulation)}

The eng zering stress and strain values were converted to true values using eqns. 6 - 9. A Bridgman correction factor of 0.87 was applied to the failure stress based on the true uniform and total strains (Tegart 1966 and Dieter 1985). The resulting true stress and strain values are given in Table 11 and illustrated in Figure 11 along with the engineering values. Lines have been drawn between the true stress and strain data on Figure 11 to illustrate the application of linear interpolation. Also shown in Figure 11 is a simple power law fit to the data at the beginning of the strain hardening and beginning of necking regions. As discussed in Section 2.1.10, either the linear interpolation or power law fit may be employed for structural analyses.

For the purposes of structural analysis, it may improve numerical stability to eliminate the yield point from the stress-strain curve (e.g. make the curve linear up to the onset of strain hardening). This adjustment would not be expected to have a significant effect on the results of the structural analysis involving large plastic strains. 


\section{PRIMARY LINER FAILURE STRAIN}

This section of the report deals with the impact of mechanical property variability and materials degradation on the failure strain of the primary liner. To a first approximation, a pressurized vessel will fail by plastic instability when the strain at any point exceeds the uniform strain. This occurs because the increase in strength due to strain hardening is less than the increase in stress due to cross sectional area decrease. Deformation localizes in the region exceeding uniform strain, and the strain in this region rapidly exceeds the failure strain (e.g. total elongation). The failure strain criteria to be employed with the waste tanks is given below (Miller 1990 and Thomas 1992a):

$$
\begin{aligned}
& \varepsilon_{f}=\frac{\varepsilon_{u}}{K_{1} K_{2} K_{3}} \\
& \text { where: } \begin{array}{ll}
\varepsilon_{f} & =\text { True failure strain, } \\
\varepsilon_{u} & =\text { True uniform strain, } \\
\mathrm{K}_{1} & =\text { Knockdown factor for structural model sophistication, } \\
\mathrm{K}_{2} & =\text { Knockdown factor for design confidence, and } \\
\mathrm{K}_{3} & =\text { Knockdown factor for materiais considerations. }
\end{array}
\end{aligned}
$$

This section deals with evaluation of $K_{3}$. The knockdown factors represent factors of safety to account for uncertainties in the structural model, design, and materials. This approach has been employed in the analysis of LWR containment vessel ;ressurization (Clauss et al. 1987 and Miller 1990), and was suggested for use in the analysis of the waste tank response to a deflagration accident by the Defense Nuclear Facilities Safety Board (DNFSB). The uniform strain is a reasonable failure criteria for pressurized vessels since it represents the point of plastic instability. However, it is very conservative failure criteria when considering localized self-limiting strains; in these cases, it is more appropriate to consider the total elongarion value.

\subsection{Effect of Mechanical Property Variability}

The waste tank structural analysis will be performed using the true stress - true strain data set given in the preliminary evaluation for primary liner (Thomas 1992c), and data similar to that given in Table 11 for the secondary liner (Thomas 1992b). As discussed in Section 2.1.10, the primary liner tensile properties given in Table 9 are essentially the same as those given in the preliminary evaluation; the only significant difference is that the tensile strength given in Table 9 is $3.3 \mathrm{ksi}$ larger than that given in the preliminary evaluation, and thus the primary liner structural analysis is conservative with respect to the values given in 
this evaluation. The secondary liner failure strain used in the structural analyses had not been corrected for strain rate, and is therefore iess than that given in Table 11 (135 vs. 144 $\mathrm{ksi}$ ); the secondary liner structural analysis is thus also conservative with respect to the values given in this evaluation.

The stress-strain curves presented in Section 2 were constructed using a conservative set of tensile data. The yield and tensile strengths were set to the average value from the mill certification test reports minus two standard deviations. Therefore, structural analyses performed using these curves as input will be generally conservative with respect to mechanical properties.

Some of the plates employed to construct the waste tanks will have strengths below those given in Tables 9 and 11. Assuming that the strength data are truly represented by a normal distribution, which is a reasonable assumption based on the distribution plots presented in Section 2, and neglecting unceitainties introduced by the strain rate and temperature corrections, then the probability that a given plate will have a yield or tensile strength below those employed in the structural model is $2.3 \%$ (Tsoulfanidis 1983).

Therefore, the appropriate issue to address the impact of mechanical property variability on the primary liner failure pressure is the impact of a small section of the liner having reduced strength (e.g. reaching the uniform strain at a lower stress). Göller et al. (1987) discuss this issue in connection with the evaluation of the failure pressure of a spherical containment vessel for a pressurized water reactor. Based on the results from a finite element structural model, they conclude that a small section with reduced properties has an insignificant impact on failure pressure. Although there are differences in material and geometry between the waste tanks and the structure examined by Göller et al. (1987), the main conclusions from their work should be applicable to the waste tanks. The effect of mechanical property variability on the primary liner failure pressure is therefore judged to be insignificant.

\subsection{Effect of Material Degradation}

Sufficient chemistry and temperature controls are in place to insure that the contents of the waste tanks do not significantly degrade the primary liner (SRS 1991). No indication of primary liner general corrosion, pitting or cracking has been observed in the visual inspections performed to date for Tanks 48 - 50 (McNatt 1981). The ultrasonic testing 
(UT) data for these tanks also show no indication of attack (McNatt 1981). A supplemental UT program examined the liquid-air interface region in the ITP demonstration tank and found no indication of primary liner degradation (Thomas i992b).

Both hydrogen embrittlement and stress corrosion cracking require that the embrittling species be transported to the crack tip in order to alter the mechanical response. At sufficiently high strain rates, the embrittling species cannot be transported at sufficient velocity to impact crack propagation, and failure occurs purely by mechanical means (Herbsleb and Schwenk 1985, Craig 1987). Strain rates in excess of $10^{-4} \mathrm{sec}^{-1}$ will prevent SCC and result in ductile fracture (Sprowls 1987, Wiersma 1992); similar strain rate thresholds have been reported for hydrogen embrittlement of low-alloy carbon steels (Maier and Kaesche 1990). As discussed in Section 2.1.8, the liner strain rates expected in a defflagration accident would be 3 orders of magnitude greater than this limit. Therefore, hydrogen embrittlement and stress corrosion cracking would not be expected to impact the response of the waste tanks to a deflagration accident. Hydrogen damage of carbon steels (e.g. the formation of $\mathrm{CH}_{4}$ ) requires temperatures in excess of approximately $200^{\circ} \mathrm{C}$ (Viswanathan 1989), and thus would also not impact the liner.

The preliminary results from an ongoing study of radiation damage to the waste tanks show that essentially no radiation-induced mechanical property changes would be anticipated for the oldest of the waste tanks (Caskey 1992). Therefore, the relatively new waste tanks of concern in this evaluation (nos.48-50) will not have accumulated sufficient radiation damage to impact mechanical properties.

Aging is normally associated with quenched or rapidly cooled steels, where free carbon above the solubility limit may form precipitates [e.g. $\mathrm{Fe}_{3} \mathrm{C}$ or compounds involving minor alloying elements ( $\mathrm{Mn}, \mathrm{Cr}$ or Mo)] over a period of time. However, the primary liner was normalized (allowed to cool slowly in still air) so that very little free carbon would exist, and thus the liner would not be subject to aging effects. Rollason (1973) reports that strain-aging has little impact on fine grained material, and that any effect is eliminated by heating to $500-650^{\circ} \mathrm{C}$ after forming. Since the primary liner plates were fabricated using a fine-grain practice and the post-fabrication stress relief treatment involved heating to $621^{\circ} \mathrm{C}$ for 1 hour, deformation introduced $b_{\text {:r }}$ plate formation operations would not lead to strainaging. 
The only significant degradation of the primary liner which has occurred is pitting of the bottom plates, including portions of the inner and outer knuckle, which occurred during the construction phase (Jenkins 1981, SRS 1981). These pits are not expected to lead to stress corrosion cracking of the bottom plates during normal operation even if the chemistry control requirements were violated (SRS 1981). The structural analysis will be performed without consideration of these pits. The actual stress in a pitted plate can be related to the stress calculated without consideration of the pits as shown below:

$$
\sigma_{p}=\sigma_{c}\left(\frac{t_{n}}{t_{p}}\right)=\sigma_{c}\left(\frac{t_{n}}{t_{n}-d_{p}}\right)
$$

$$
\text { where. } \begin{array}{ll}
\sigma_{\mathrm{p}} & =\text { Actual stress (considering pitting), } \\
\sigma_{\mathrm{c}} & =\text { Calculated stress (ignoring pitting), } \\
\mathrm{t}_{\mathrm{n}} & =\text { Nominal plate thickness, } \\
\mathrm{t}_{\mathrm{p}} & =\text { Effective plate thickness (considering pitting), and } \\
\mathrm{d}_{\mathrm{p}} & =\text { Effective pit depth. }
\end{array}
$$

Therefore, when the actual stress reaches the tensile strength $\left(\sigma_{u}\right)$, the corresponding calculated stress will be:

$$
\sigma_{c}=\sigma_{u}\left(1-\frac{d_{p}}{t_{n}}\right)
$$

This formulation assumes that the pitted region is incapable of supporting any load. Equations 11 and 12 are valid for either the stress resulting from a uniaxial load, or for an equivalent stress parameter, such as the Von Mises stress, under a multiaxial load. The strain corresponding to the calculated stress given by eqn.(12) may be estimated from the stress-strain curves given in Figure 7. It is recognized that this is not strictly applicable for a multiaxial stress state, but this approach provides an estimate which is judged to be acceptable for the purposes of this evaluation. The linear interpolation and power law fits shown in Figure 7 are given below:

$$
\begin{aligned}
& \sigma=51.5+224.1(\varepsilon) \\
& \sigma=135(\varepsilon)^{0.225}
\end{aligned}
$$

The caiculated strain corresponding to the actual strain reaching the uniform strain (e.g. the actual stress reaching the tensile strength) may be computed by substituting eqn.(12) into eqns. (13) and (14) and solving for strain. The maximum pit depth for tanks 48-50 was reported to be 0.08 " (SRS 1981). An effective pit depth of 0.06 " is therefore judged to be 
conservative. The resulting uniform strains are given in Table 12; these values should be employed to calculate the failure criterion given as eqn.(10).

\subsection{Net Adjustment to Primary Liner Failure Strain}

Based on the discussions above, the effect of mechanical property variability and materials degradation on the primary liner failure strain is expected to be insignificant. A $\mathrm{K}_{3}$ knockdown factor of 1.05 is judged to be conservative and is recommended. The uniform strains to be employed with the failure criterion (eqn.10) for the bottom plates and bottom knuckles are given in Table 12; for the remainder of the primary liner, the uniform strain value given in Table $9\left(\varepsilon_{\mathbf{u}}=0.182\right)$ should be employed. 


\section{CONCLUSIONS}

True stress - true strain curves for ASTM A537 Class 1 and A516 Grade 70 carbon steels, the materials employed to construct the primary and secondary liners, were constructed. These curves are based upon the mill certification test reports for the plates employed to construct the waste tanks of interest, typical manufacturers data, tensile tests conducted at SRS, and literature data. The data selected to construct the curves are conservative. The effects of strain rate, temperature, and necking were addressed.

The effects of mechanical property variabilitv and materials degradation on the primary liner failure strain are expected to be insignificant. The stress-strain curves developed in this report were used as input to the waste tank structural analysis, so that the results from the analysis are conservative with respect to mechanical property variability. The chemistry and temperature controls placed on waste tank operations insure that the contents of the waste tank do not attack the primary liner to any significant degree; this conclusion is supported by the available inspection data. It was shown that the response of the primary liner to a deflagration accident would not be impacted by stress corrosion cracking, hydrogen embrittlement, hydrogen damage, radiation damage, aging, or strain aging. A conservative knockdown factor $\left(\mathrm{K}_{3}\right)$ of 1.05 on the primary liner failure strain to account for these effects was reconimended. Reduced uniform strain values are provided to account for the effects of pits in the bottom plates and knuckles. 


\section{REFERENCES}

Alloy Digest (1967a) "USS Char-Pac," Filing Code CS-26, Feb. 1967.

Alloy Digest (1967b) "Lukens LT-75," Filing Code CS-20, Dec. 1963.

Alloy Digest (1971) "Bethlehem RQC-60," Filing Code CS-42, July 1971.

ASTM Standard A 537 - 86 (1989) "Standard Specification for Pressure Vessel Plates, Heat-Treated, Carbon-Manganese-Silicon Steel," ASTM, Phil., PA.

Bethlehem (1977) ROC-60 Roller Quenched and Tempered or Normalized Carbon Steel Plate: Fabrication and Welding Data, Booklet 2678-B, Bethlehem Steel, Bethlehem, PA.

Brockenbrough, R.L. and B.G. Johnston (1968) USS Steel Design Manual, ADUSS 27 3400-02, United States Steel Corp., Pittsburgh, PA.

Caskey, G.R. (1992) An Estimate of Radiation Damage to Storage Tanks for High Level Waste, WSRC-TR-92-350, Aug. 1992, draft copy.

Chow, J.G.Y., S.B. McRickard and D.H. Gurinsky (1963) "Mechanical Properties of Irradiated Iron and Iron Alloys," in Radiation Effects on Metals and Neutron Dosimetry, ASTM Special Publication No. 34! (ASTM STP-341), ASTM, Philadelphia, PA, pp. 47-66

Clauss, D.B., D.S. Horschel and T.E. Blejwas (1987) "Insights into the Behavior of LWR Steel Containment Buildings During Severe Accidents," Nucl.Eng.Des, 100: 189-204 (presented at the Intl. Seminar on Containment of Nuclear Reactors, in conjunction with the 8th SMIRT Conf., Brussels, Belgium, 26-27 Aug. 1985).

Craig, B. (1987) "Environmentally Induced Cracking," in Corrosion - Vol.13 of The Metals Handbook - 9th Ed, ASM Intl., Metals Park, OH, pp. 145-189.

Dieter, G.E. (1985) "Mechanical Behavior of Materials Under Tension," in Metals Handbook. 9th Ed. Vol 8. Mechanical Testing, ASM, Metals Park, OH, pp.20-7.

Göller, B., R. Krieg, G. Messemmer and E. Wolf (1987) "On The Failure of Spherical Steel Containments Under Excessive Internal Pressure," Nucl.Eng.Des., 100: 205-19.

Gong, C. (1991) Response of a Type III Waste Tank to Hydrogen Deflagration, WSRCTR-91-452, Westinghouse Savannah River Co., Aiken, SC, Aug. 1991.

Gross, J.H. (1964) PVRC Interpretive Report of Pressure Vessel Research. Section 2 Materials Considerations, Bulletin No. 101, Pressure Vessel Research Committee of The Welding Research Council, New York, NY, Nov. 1964.

Herbsleb, G. and W. Schwenk (1985) "The Influence of Dynamic Mechanical Parameters on Stress Corrosion Craclomg pf Steel - A Review," Corr, 41(8): 431-7.

Jenkins, C.F. (1980) Pitted Waste Tank Nos, 48-51 - Cleaning and Inspection, 200-F/H Area Metallurgical Report, Savannah River Site, Aiken, SC, 10/8/81. 
Jenkins, C.F. (1981) Stress Relief Summary for Waste Tank Nos.48-51, 200-H Area Metallurgical Report, Savannah River Site, Aiken, SC, 2/14/80.

Maier, H.J. and H. Kaesche (1990) "Aspects of Hydrogen Effects on Fracture Processes in Low Alloy Stee!." in Hydrogen Effects on Material Behavior, TMS, Warrendale, PA, pp. 733-44.

McNatt, F.G. (1981) 1980 Waste Tank Insfection Program, DPSPU-81-011-019. Savannah River Site, Aiken, SC (reports for 1982 through 1991 are DPSPU-82-011019. DPSPU-83-011-019. DPSPU-84-011-019, DPSP-86-1024, DPSP-86-1041, DPSP-87-1035, DPSP-88-141-001, DPSP-89-141-001, WSRC-TR-90-166 and WSRC-TR-91-166).

Miller, R.F. and I.J. Heger (1950) Report on The Strength of Wrought Steels at Elevated Temperatures, Special Tech. Publ. No. 100, ASTM, Phil., PA.

Miller, J.D. (1990) Analysis of Shell-Rupture Failure Due to Hypothetical ElevatedTemperature Pressurization of the Sequoyah Unit \& Steel Containment Building, NUREG/CR-5405, SAND89-1650, Sandia National Laboratories, Albuquerque, NM, Feb. 1990.

Mindlin, H. and Ho, C.Y., eds. (1990) Siructural Alloys Handbook, Vol. 3, Metals and Ceramics Information Center, Battelle - Columbus Laboratories, Columbus, $\mathrm{OH}$.

Nuclear Systems Materials Handbook (1987) Yol. - Design Data. Part 1 - Structural Materials. Groun 3 - Carbon Steels. Section 3-Medium Carbon Steels, TID-26666, Oak Ridge National Laboratory, Oak Ridge, TN.

Peacock, H.B. (1975) Ductile Foacture Tests of Mild Steel, DPST-75-301_Savannah River Site, Aiken, SC, April 1975.

Roe, G.J. and R.H. Sterne Jr. (1.978) "Carbon and Low-Alloy Steel Plate," in Metals Handbook. 9th Ed. Vol. 1. Properties and Selection: Irons and Steels, ASM, Metals Park, OH.

Rollason, E.C. (1973) Metallurgy for Engineers, Edward Amold, London.

Shurrab, M.S. (1992) Personal Communication, WSRC, May 1992.

Simmons, W.G. and H.C. Cross (1955) Eleyated-Temperature Properties of Carbon Steels, Special Tech. Publ. No. 180, ASTM, Phil., PA.

Sprowis, D.O. (1987) "Evaluation of Stress-Corrosion Cracking," in Corrosion - Vol.13 of The Metals Handbook - 9th Ed, ASM Intl., Metals Park, OH, pp. 245-282.

SRS (1977) Waste Tank Farms Technical Standard, DPSTS-241, Savannah River Site, Aiken, SC, March 1977.

SRS (1978a) "Savannah River Plant - Bldg. 241-51H Tks. 48, 49, 50 and 51 - Additional Waste Storage Tanks - Primary Tank Plans \& Details - Steel," SRS Drawing W707112 Rev. 10, Project 9S1828, Savannah River Site, Aiken, SC, 11/6/78.

SRS (1978b) Specification 7182 - Primary and Secondary Steel Tanks for Project 9S1828, Rev. 5/23/78, Savannah River Site, Aiken, SC. 
SRS (1981) Investigation of Pitting in Primary Bottom Plates of Type III Waste Tanks, DPE-3687, Savannah River Site, Aiken, SC, December 1981.

SRS (1991) Westinghouse Savannah River Company - Additional Analysis for DWPE Feed Preparation by In-Tank Processing, DPSTSA-200-10, SUP 18, Addendum 1, Rev.1, Savannah River Site, Aiken, SC.

Tegart, W.J.M. (1966) Elements of Mechanical Metallurgy, MacMillan Co., New York, NY, p. 22.

Thomas, J.K. (1992a) "Failure Strain Criteria for the Type III Waste Tanks," Task Plan, NRTSC Task No. 92-054-1, Savannah River Site, Aiken, SC, 5/15/92.

Thomas, J.K. (1992b) SRS Lab Notebook WSRC-NB-90-227, Savannah River Site, Aiken, SC.

Thomas, J.K. (1992c) "Mechanical Property Data for Type III Waste Tank Primary Liner (ASTM A537 Class 1 Carbon Steel," SRT-MTS-92-1111, Savannah River Site, Aiken, SC, 5/27/92.

Tsoulfanidis, N. (1983) Measurement and Detection of Radiation, McGraw-Hill, New York, NY, p. 50.

USS (1982) Properties Card - Char-Pac Steel Plates, ADUSS 16-3577-05, United States Steel, Pittsburgh, PA.

Viswanathan, R. (1989) Damage Mechanisms and Life.Assessment of High-Temperature Components, ASM Intl., Metals Park, OH, p. 360.

Voorhees, H.R. (1969) A Suryey of Effects of Lower-Than-Usual Rates of Strain on the Yield and Tensile Strengths of Metals, Data Series DS 44, ASTM, Phil., PA.

Wallace, R.M. and W.W.F. Yau (1986) Consequences of Explosion in a Type III Tank, DPST-86-817, Savannah River Site, Aiken, SC, December 1986.

Wiersma, B.J. (1992a) Constant Extension Rate Tensile Tests on 304L Stainless Steel in Simulated Hazardous Low-Level Waste, WSRC-TR-92-229, Westinghouse Savannah River Co., Aiken, SC, April 1992.

Wiersma, B.J. (1992b) SRS Lab Notebook WSRC-NB-91-43, Savannah River Site, Aiken, SC. 
Table 1 Tensile Property and Chemical Composition Requirements for ASTM A537 Class 1 and A516 Grade 70 Carbon Steels.

\begin{tabular}{|l|c|c|}
\hline \multicolumn{1}{|c|}{ Physical Quantity } & A537 Class 1 & A516 Grade 70 \\
\hline Tensile Properties: [a] & & \\
Yield Strength (ksi) & 50 & 38 \\
Tensile Strength (ksi) [b] & $70-90$ & $70-90$ \\
Total Elong. (\%) [over 2"] & 22 & 21 \\
Total Elong. (\%) [over 8"] & 18 & 17 \\
& & \\
Chemical Composition: [c, d] & & \\
C (wt.\%) & 0.24 & 0.27 \\
Mn (wt.\%) & $0.70-1.35$ & $0.85-1.20$ \\
P (wt.\%) & 0.035 & 0.035 \\
S (wt.\%) & 0.04 & 0.04 \\
Si (wt.\%) & $0.15-0.50$ & $0.15-0.40$ \\
Cu (wt.\%) & 0.35 & $0.40[\mathrm{e}]$ \\
Ni (wt.\%) & 0.25 & $0.40[\mathrm{e}]$ \\
Cr (wt.\%) & 0.25 & $0.30[\mathrm{e}]$ \\
Mo (wt.\%) & 0.08 & $0.12[\mathrm{e}]$ \\
\hline
\end{tabular}

Notes: [a] Tensile properties for plate thickness $2.5^{n}$ or less (A 537) and $1 / 2^{n}$ or less (A 516).

[b] Both a minimum and maximum allowable are set for tensile strength.

[c] One composition limit value denotes a maximum allowed, while two values indicate a required range.

[d] Composition limits for beat analysis (slightly more variance allowed for product analysis). The A $537 \mathrm{Mn}$ range is for plate thickness $1.5^{n}$ or less. The A $516 \mathrm{C}$ value and $\mathrm{Mn}$ range are for plate thickness $1 / 2^{\text {" or less. }}$

[e] These limits are per ASTM A20, sum to exceed 1.00\%. 
Table 2 Actual vs. Min. Properties for Lukens LT-75N Steel Plate.

\begin{tabular}{|c|cc|c|c|c|c|}
\hline \multirow{2}{*}{$\begin{array}{c}\text { Plate } \\
\text { Thickness }\end{array}$} & \multicolumn{2}{|c|}{$\begin{array}{c}\text { Yield Strength } \\
\text { (ksi) }\end{array}$} & \multicolumn{2}{c|}{$\begin{array}{c}\text { Tensile Strength } \\
\text { (ksi) [UTS] }\end{array}$} & \multicolumn{2}{c|}{$\begin{array}{c}\text { Total Elongation (\%) } \\
\text { (over 8" gauge) }\end{array}$} \\
\cline { 2 - 7 } & (actual) & (min.) & (actual) & (min.) & (actual) & (min.) \\
\cline { 2 - 7 } $3 / 8$ & 54.2 & 50 & 77.3 & 70 & 26 & 20 \\
$1 / 2$ & 55.4 & 50 & 79.0 & 70 & 27 & 20 \\
$5 / 8$ & 51.0 & 50 & 73.4 & 70 & 29 & 20 \\
$3 / 4$ & 51.9 & 50 & 76.4 & 70 & 27 & 20 \\
1 & 51.1 & 50 & 73.2 & 70 & 26 & 20 \\
2 & 50.8 & 46 & 69.8 & 65 & 25 & $\mathrm{n} / \mathrm{a}$ \\
\hline
\end{tabular}

Table 3 Actual vs. Min. Properties for Armco LO-TEMP Steel Plate.

\begin{tabular}{|c|c|c|c|c|c|c|}
\hline \multirow{2}{*}{$\begin{array}{c}\text { Plate } \\
\text { Thickness } \\
\text { (inches) }\end{array}$} & \multicolumn{2}{|c|}{$\begin{array}{c}\text { Yield Strength } \\
\text { (ksi) }\end{array}$} & \multicolumn{2}{c|}{$\begin{array}{c}\text { Tensile Strength } \\
\text { (ksi) [UTS] }\end{array}$} & \multicolumn{2}{c|}{$\begin{array}{c}\text { Total Elongation (\%) } \\
\text { (over 2" gaige) }\end{array}$} \\
\cline { 2 - 8 } & (actual) & (min.) & (actual) & (min.) & (actual) & (min.) \\
\cline { 2 - 7 } $1 / 4$ & 57.2 & 50 & 78.5 & 70 & 27 & 22 \\
$1 / 2$ & 58.6 & 50 & 80.3 & 70 & 28 & 22 \\
$3 / 4$ & 55.9 & 50 & 80.7 & 70 & 26 & 22 \\
1 & 52.0 & 50 & 76.0 & 70 & 31 & 22 \\
$1 \& 1 / 4$ & 51.3 & 50 & 75.3 & 70 & 36 & 22 \\
$1 \& 1 / 2$ & 50.3 & 46 & 70.7 & 65 & 34 & 22 \\
\hline
\end{tabular}


Table 4 A537 Class 1 Plates Employed to Construct Tanks 48 - 51 (All Plates).

\begin{tabular}{|c|c|c|c|c|c|c|}
\hline \multirow{2}{*}{$\begin{array}{l}\text { Physical } \\
\text { Quantity }\end{array}$} & \multirow{2}{*}{$\begin{array}{c}\text { ASTM } \\
\text { Standard }\end{array}$} & \multirow{2}{*}{$\begin{array}{l}\text { Min. } \\
\text { Value }\end{array}$} & \multirow{2}{*}{$\begin{array}{l}\text { Max. } \\
\text { Value }\end{array}$} & \multirow{2}{*}{$\begin{array}{l}\text { Avg. } \\
\text { Value }\end{array}$} & \multicolumn{2}{|c|}{ Standard Deviation } \\
\hline & & & & & Absolute & Relative (\%) \\
\hline Tensile Properties: & & & & & & \\
\hline Yield Strength (ksi) & 50 & 51 & 64 & 56.7 & 2.5 & 4.4 \\
\hline Tensile Strength (ksi) & $70-90$ & 70 & 88 & 79.3 & 2.2 & 2.8 \\
\hline Elong. (\%) [over 8"] & 18 & 18 & 50 & 24.8 & 3.5 & 14 \\
\hline Chemical Composition: & & & & & & \\
\hline$C$ (wt.\%) & 0.24 & 0.14 & 0.23 & 0.18 & 0.011 & 6.0 \\
\hline $\operatorname{Mn}(w t . \%)$ & $0.70-1.35$ & 1.14 & 1.30 & 1.21 & 0.042 & 3.4 \\
\hline P (wt.\%) & 0.035 & 0.005 & 0.014 & 0.009 & 0.002 & 27 \\
\hline$S(w t . \%)$ & 0.04 & 0.01 & 0.03 & 0.02 & 0.003 & 20 \\
\hline Si (wt.\%) & $0.15 \cdot 0.50$ & 0.23 & 0.42 & 0.30 & 0.029 & 9.7 \\
\hline $\mathrm{Cu}(\mathrm{wt} . \%)$ & 0.35 & 0.20 & 0.29 & 0.24 & 0.014 & 6.1 \\
\hline $\mathrm{Ni}(\mathrm{wt. \%})$ & 0.25 & 0.07 & 0.23 & 0.20 & 0.019 & 9.4 \\
\hline $\mathrm{Cr}(\mathrm{wt.} \%)$ & 0.25 & 0.12 & 0.22 & 0.16 & 0.024 & 16 \\
\hline Mo (wt.\%) & 0.08 & 0.03 & 0.07 & 0.05 & 0.014 & 28 \\
\hline
\end{tabular}


Table 5 A537 Class 1 Plates Employed to Construct Tanks 48 - 51 (1/2" Plates).

\begin{tabular}{|c|c|c|c|c|c|c|}
\hline \multirow{2}{*}{$\begin{array}{l}\text { Physical } \\
\text { Quantity }\end{array}$} & \multirow{2}{*}{$\begin{array}{c}\text { ASTM } \\
\text { Standard }\end{array}$} & \multirow{2}{*}{$\begin{array}{l}\text { Min. } \\
\text { Value }\end{array}$} & \multirow{2}{*}{$\begin{array}{l}\text { Max. } \\
\text { Value }\end{array}$} & \multirow{2}{*}{$\begin{array}{l}\text { Avg. } \\
\text { Value }\end{array}$} & \multicolumn{2}{|c|}{ Standard Deviation } \\
\hline & & & & & Absolute & Relative (\%) \\
\hline Tensile Properties: & & & & & & \\
\hline Yield Strength (ksi) & 50 & 53 & 64 & 57.9 & 2.1 & 3.7 \\
\hline Tensile Strength (ksi) & $70-90$ & 72 & 88 & 79.8 & 2.2 & 2.8 \\
\hline Elong. (\%) [over 8"] & 18 & 18 & 48 & 24.0 & 2.8 & 12 \\
\hline Chemical Composition: & & & & & & \\
\hline $\mathrm{C}(\mathrm{wt} . \%)$ & 0.24 & 0.14 & 0.23 & 0.18 & 0.012 & 6.9 \\
\hline $\operatorname{Mn}(w t . \%)$ & $0.70-1.35$ & 1.14 & 1.30 & 1.22 & 0.046 & 3.8 \\
\hline$P(w t \%)$ & 0.035 & 0.005 & 0.014 & 0.009 & 0.003 & 31 \\
\hline$S(w t . \%)$ & 0.04 & 0.01 & 0.02 & 0.02 & 0.002 & 17 \\
\hline $\mathrm{Si}$ (wt.\%) & $0.15 \cdot 0.50$ & 0.23 & 0.42 & 0.31 & 0.028 & 9.0 \\
\hline $\mathrm{Cu}(\mathrm{wt} . \%)$ & 0.35 & 0.22 & 0.29 & 0.24 & 0.016 & 6.8 \\
\hline $\mathrm{Ni}(\mathrm{wt} \%)$ & 0.25 & 0.18 & 0.23 & 0.20 & 0.014 & 6.9 \\
\hline $\mathrm{Cr}(\mathrm{wt} . \%)$ & 0.25 & 0.12 & 0.21 & 0.15 & 0.021 & 14 \\
\hline Mo (wt.\%) & 0.08 & 0.03 & 0.07 & 0.05 & 0.015 & 30 \\
\hline
\end{tabular}


Table 6 Tensile Property Summary for Plates Employed to Construct Tanks 48 - 51.

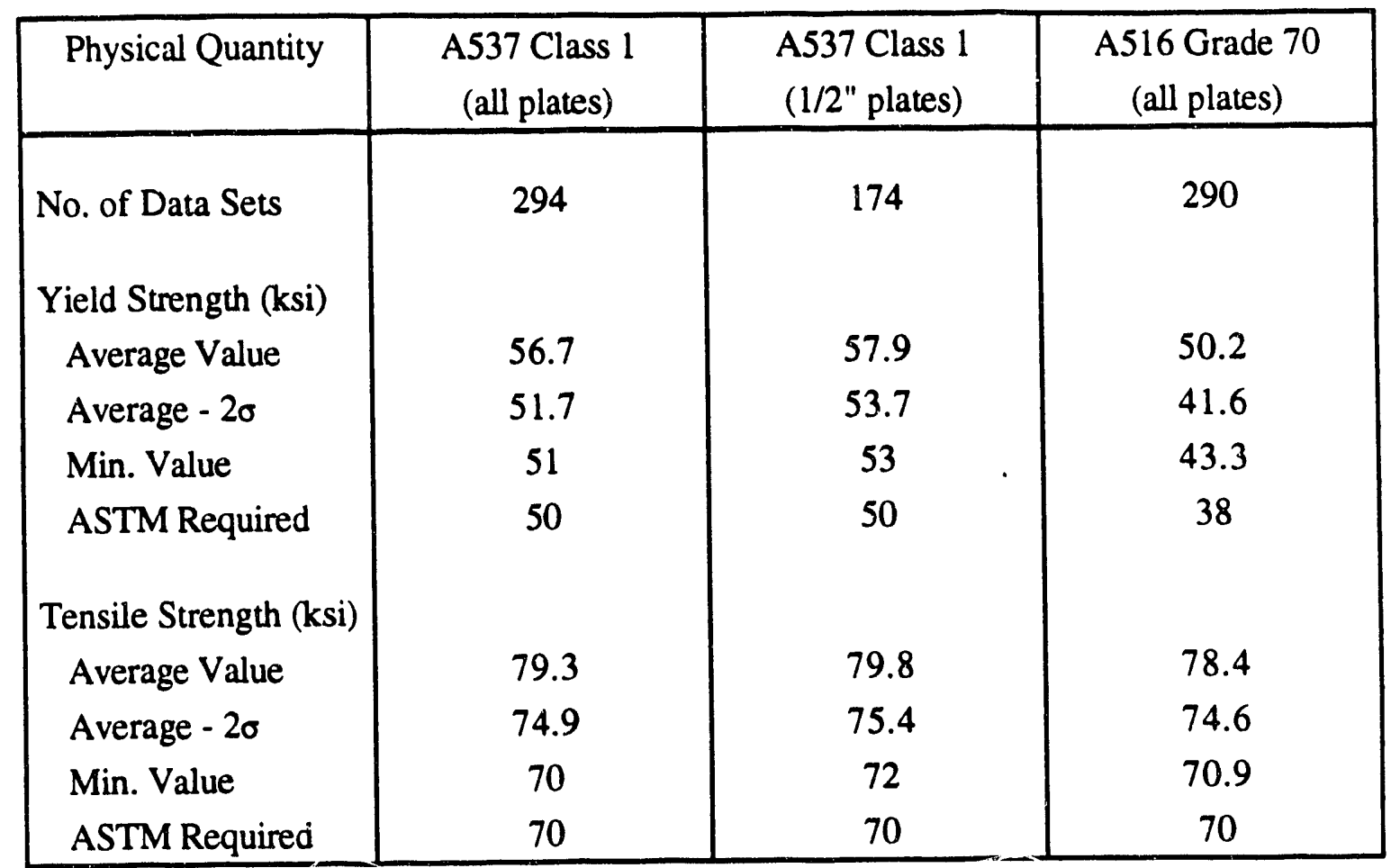

Table 7 Results From MTS A537 Class 1 CERT Tests.

\begin{tabular}{|l|c|c|}
\hline \multicolumn{1}{|c|}{ Mechanical Property } & Test in Air & Test in Soln. (Avg.) \\
\hline Temperature ( $\left.{ }^{\circ} \mathrm{C}\right)$ & $20-30$ & 60 \\
Strain Rate $\left(\mathrm{sec}^{-1}\right)$ & $5 \times 10^{-4}$ & $1 \times 10^{-6}$ \\
Yield Strength (ksi) & 55.0 & 51.2 \\
Tensile Strength (ksi) & 83.0 & 76.2 \\
Uniform Elongation (\%) & 17.0 & 15.7 \\
Stress at Failure (ksi) & 69.4 & 61.6 \\
Total Elongation (\%) & 28.5 & 25.8 \\
Reduction in Area (\%) & not measured & 55.6 \\
\hline
\end{tabular}


Table 8 A537 Class 1 Nominal and Adjusted Tensile Properties (Eng. Formulation).

\begin{tabular}{|l|c|c|c|c|c|}
\hline \multirow{2}{*}{$\begin{array}{c}\text { Mechanical } \\
\text { Property }\end{array}$} & \multirow{2}{*}{$\begin{array}{c}\text { Nominal } \\
\text { Value }\end{array}$} & \multicolumn{3}{|c|}{ Property Correction Factors } & Net \\
\cline { 3 - 5 } & & Temp. & Strain Rate & Combined & Value \\
\hline & & & & & \\
Yield Strength (ksi) & 53.7 & 0.90 & 1.13 & 1.02 & 54.8 \\
Tensile Strength (ksi) & 75.4 & 0.95 & 1.07 & 1.02 & 76.9 \\
Uniform Elongation (\%) & 18 & 1.11 & 1 & 1.11 & 20.0 \\
Stress at Failure (ksi) & 61 & 0.95 & 1.07 & 1.02 & 62.0 \\
Total Elongation (\%) & 27 & 0.85 & 1 & 0.85 & 23.0 \\
Reduction in Area (\%) & 60 & 0.95 & 1 & 0.95 & 57.0 \\
Young's Modulus (ksi) & 29,000 & 0.98 & 1 & 0.98 & $28.4 \times 10^{3}$ \\
Poisson's Ratio & 0.33 & 1 & 1 & 1 & 0.33 \\
\hline
\end{tabular}

Table 9 Recommended Property Data for A537 Class 1 Steel (Primary Liner).

\begin{tabular}{|c|c|c|c|c|}
\hline \multirow{2}{*}{$\begin{array}{l}\text { Physical Location on } \\
\text { Stress-Strain Curve }\end{array}$} & \multicolumn{2}{|c|}{ Engineering Formulation } & \multicolumn{2}{|c|}{ True Formulation } \\
\hline & $\begin{array}{l}\text { Stress } \\
\text { (ksi) }\end{array}$ & $\begin{array}{c}\text { Strain } \\
\text { (unitless) }\end{array}$ & $\begin{array}{l}\text { Stress } \\
\text { (ksi) }\end{array}$ & $\begin{array}{c}\text { Strain } \\
\text { (unitless) }\end{array}$ \\
\hline Yield & 54.8 & 0.0019 & 54.9 & 0.0019 \\
\hline Initiate Strain Hardening & 54.8 & 0.02 & 56.0 & 0.0198 \\
\hline Initiate Necking (UTS) & 76.9 & 0.20 & 92.3 & 0.182 \\
\hline Failure & 62.0 & 0.23 & 144 & 0.84 \\
\hline Failure (with necking correction) & $\mathrm{n} / \mathrm{a}$ & $\mathrm{n} / \mathrm{a}$ & 124 & 0.84 \\
\hline Density $\left(\mathrm{lb} / \mathrm{in}^{3}\right)$ & 0.284 & & & \\
\hline Young's Modulus (ksi) & 28,400 & & & \\
\hline Poisson's Ratio (unitless) & 0.33 & & & \\
\hline
\end{tabular}


Table 10 A516 Grade 70 Plates Employed to Construct Tanks 48 - 51.

\begin{tabular}{|c|c|c|c|c|c|c|}
\hline \multirow{2}{*}{$\begin{array}{l}\text { Physical } \\
\text { Quantity }\end{array}$} & \multirow{2}{*}{$\begin{array}{c}\text { ASTM } \\
\text { Standard }\end{array}$} & \multirow{2}{*}{$\begin{array}{l}\text { Min. } \\
\text { Value }\end{array}$} & \multirow{2}{*}{$\begin{array}{l}\text { Max. } \\
\text { Value }\end{array}$} & \multirow{2}{*}{$\begin{array}{l}\text { Avg. } \\
\text { Value }\end{array}$} & \multicolumn{2}{|c|}{ Standard Deviation } \\
\hline & & & & & Absolute & Relative (\%) \\
\hline Tensile Properties: & & & & & & \\
\hline Yield Strength (ksi) & 38 & 43.3 & 75.8 & 50.2 & 4.3 & 8.5 \\
\hline Tensile Strength (ksi) & $70-90$ & 70.9 & 86.4 & 78.4 & 1.9 & 2.5 \\
\hline Elong. (\%) [over 8"] & 17 & 17.0 & 30.0 & 24.6 & 2.5 & 10 \\
\hline Chemical Composition: & & & & & & \\
\hline$C(w t . \%)$ & 0.27 & 0.22 & 0.27 & 0.24 & 0.011 & 4.4 \\
\hline $\operatorname{Mn}(w t . \%)$ & $0.85-1.20$ & 0.92 & 1.09 & 1.00 & 0.051 & 5.1 \\
\hline$P(w t . \%)$ & 0.035 & 0.012 & 0.026 & 0.021 & 0.004 & 19.7 \\
\hline$S(w t . \%)$ & 0.04 & 0.015 & 0.040 & 0.027 & 0.007 & 25.3 \\
\hline Si (wt.\%) & $0.15-0.40$ & 0.200 & 0.270 & 0.233 & 0.015 & 6.5 \\
\hline
\end{tabular}

Table 11 Recommended Property Data for A516 Grade 70 Steel iecondary Liner).

\begin{tabular}{|l|c|c|c|c|}
\hline \multicolumn{1}{c|}{$\begin{array}{c}\text { Physical Location on } \\
\text { Stress-Strain Curve }\end{array}$} & \multicolumn{2}{|c|}{ Engineering Formulation } & \multicolumn{2}{c|}{ True Formulation } \\
\cline { 2 - 5 } & $\begin{array}{c}\text { Stress } \\
(\mathrm{ksi})\end{array}$ & $\begin{array}{c}\text { Strain } \\
\text { (unitless) }\end{array}$ & $\begin{array}{c}\text { Stress } \\
(\mathrm{ksi})\end{array}$ & $\begin{array}{c}\text { Strain } \\
\text { (unitless) }\end{array}$ \\
\hline & & & & \\
Yield & 47.0 & 0.0016 & 47.1 & 0.0016 \\
Initiate Strain Hardening & 47.0 & 0.015 & 47.7 & 0.0149 \\
Initiate Necking (UTS) & 79.8 & 0.18 & 94.2 & 0.166 \\
Failure & $-\cdots$ &.--- & 166 & 0.92 \\
Failure (with necking correction) & $\mathrm{n} / \mathrm{a}$ & $\mathrm{n} / \mathrm{a}$ & 144 & 0.92 \\
\hline & & & & \\
Density (lb/in ${ }^{3}$ ) & 0.284 & & \\
Young's Modulus (ksi) & 29,000 & & & \\
Poisson's Ratio (unitless) & 0.33 & & & \\
\hline
\end{tabular}


Table 12 Uniform Strain Values Considering Effect of Pitting.

\begin{tabular}{|c|c|c|c|c|}
\hline \multirow{2}{*}{$\begin{array}{l}\text { Primary } \\
\text { Liner } \\
\text { Component }\end{array}$} & \multirow{2}{*}{$\begin{array}{c}\text { Plate } \\
\text { Thickness } \\
\text { (inches) }\end{array}$} & \multirow{2}{*}{$\begin{array}{l}\text { Calc. Stress Corresponding to } \\
\text { the Actual Stress Reaching the } \\
\text { Tensile Strength Value }\end{array}$} & \multicolumn{2}{|c|}{ Corresponding Calculated Strain } \\
\hline & & & $\begin{array}{c}\text { Linear } \\
\text { Interpolation }\end{array}$ & $\begin{array}{c}\text { Power Law } \\
\text { Fit }\end{array}$ \\
\hline Bottom & $1 / 2$ & 81.2 & 0.133 & 0.105 \\
\hline Inner Knuckle & $5 / 8$ & 33.4 & 0.143 & 0.118 \\
\hline Outer Knuckle & $7 / 8$ & 86.0 & 0.154 & 0.135 \\
\hline All Others & - & 92.3 & 0.182 & 0.182 \\
\hline
\end{tabular}

Note: Stress values calculated assuming an effective pit depth of $0.06^{\prime \prime}$. 


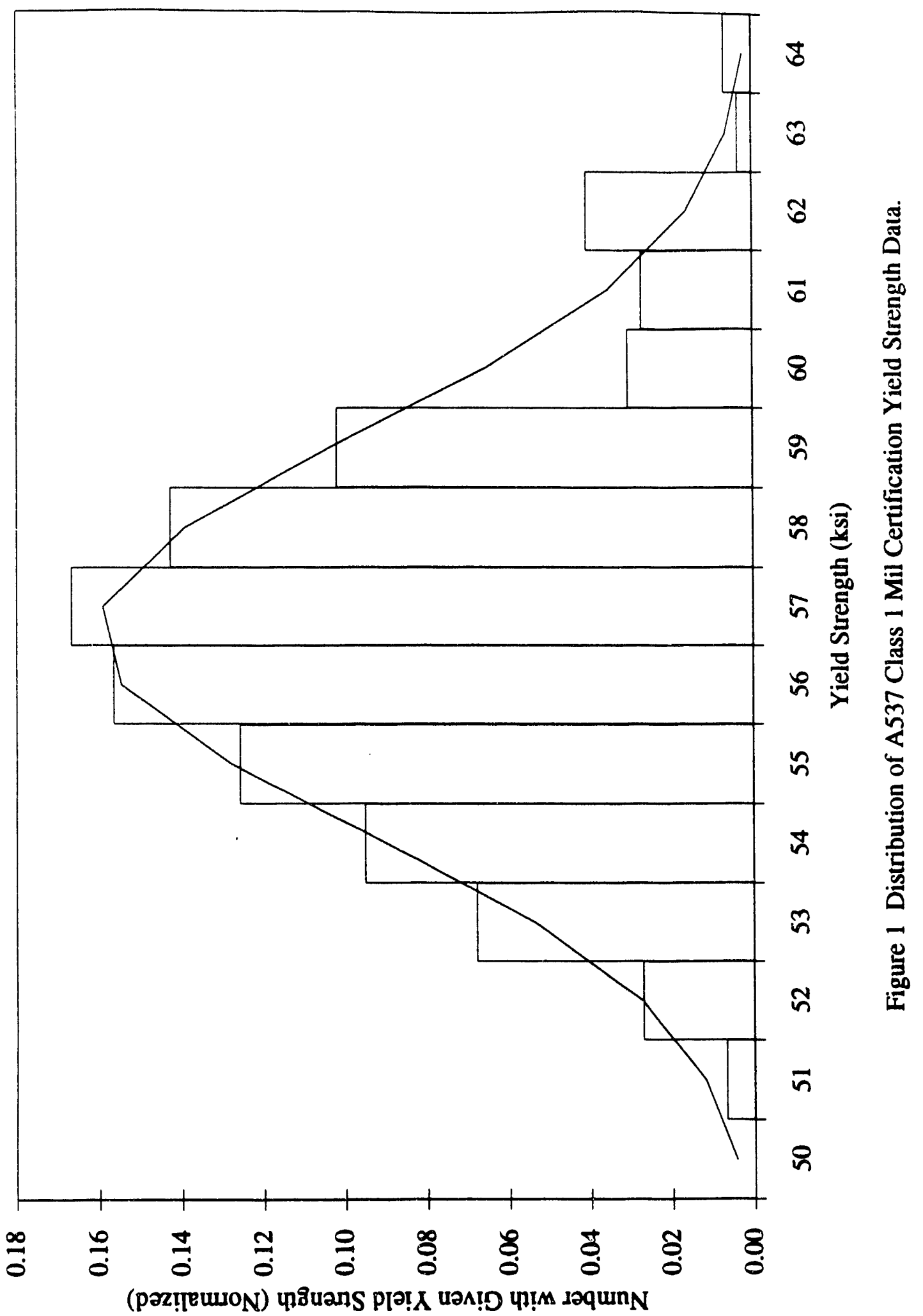




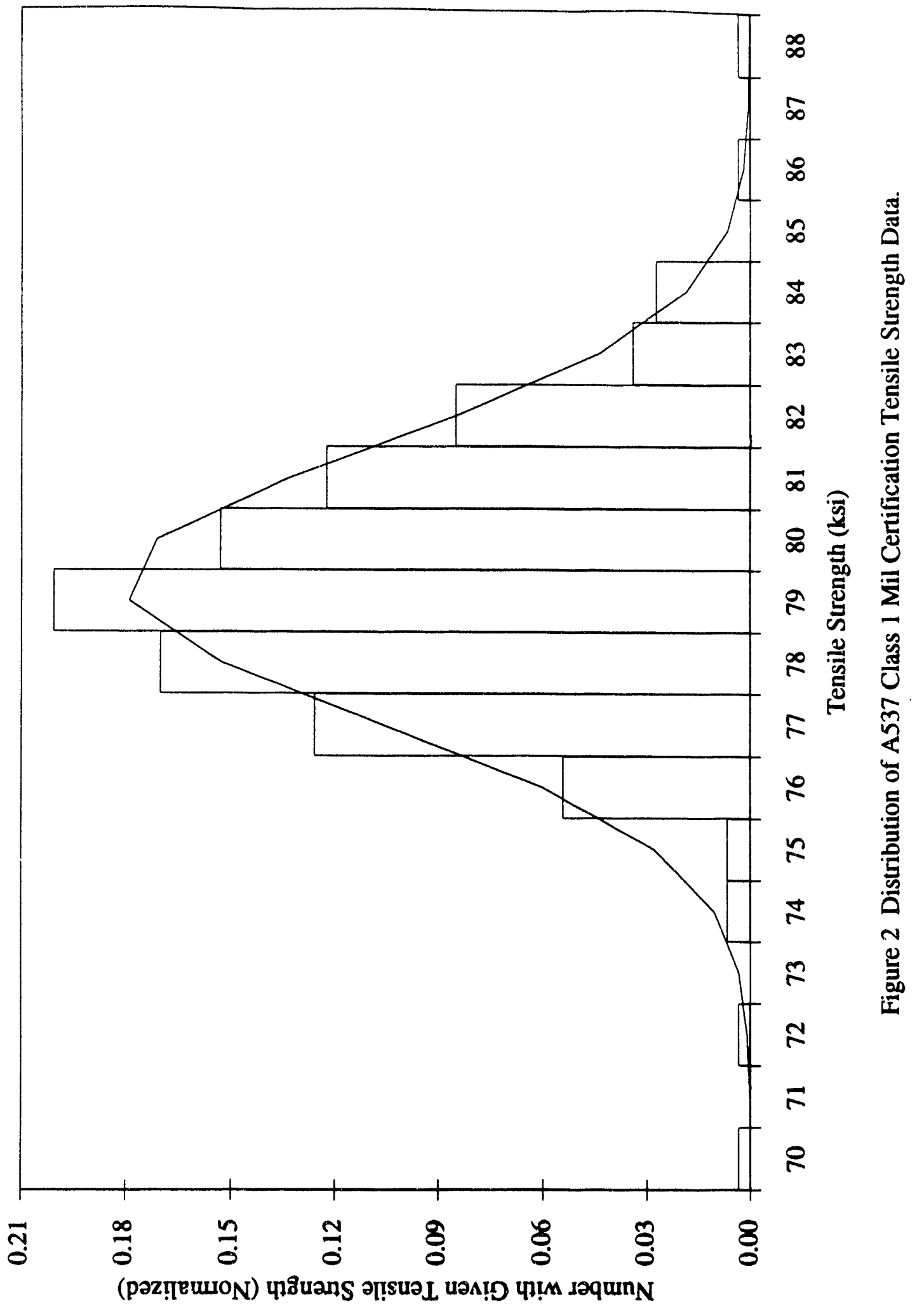




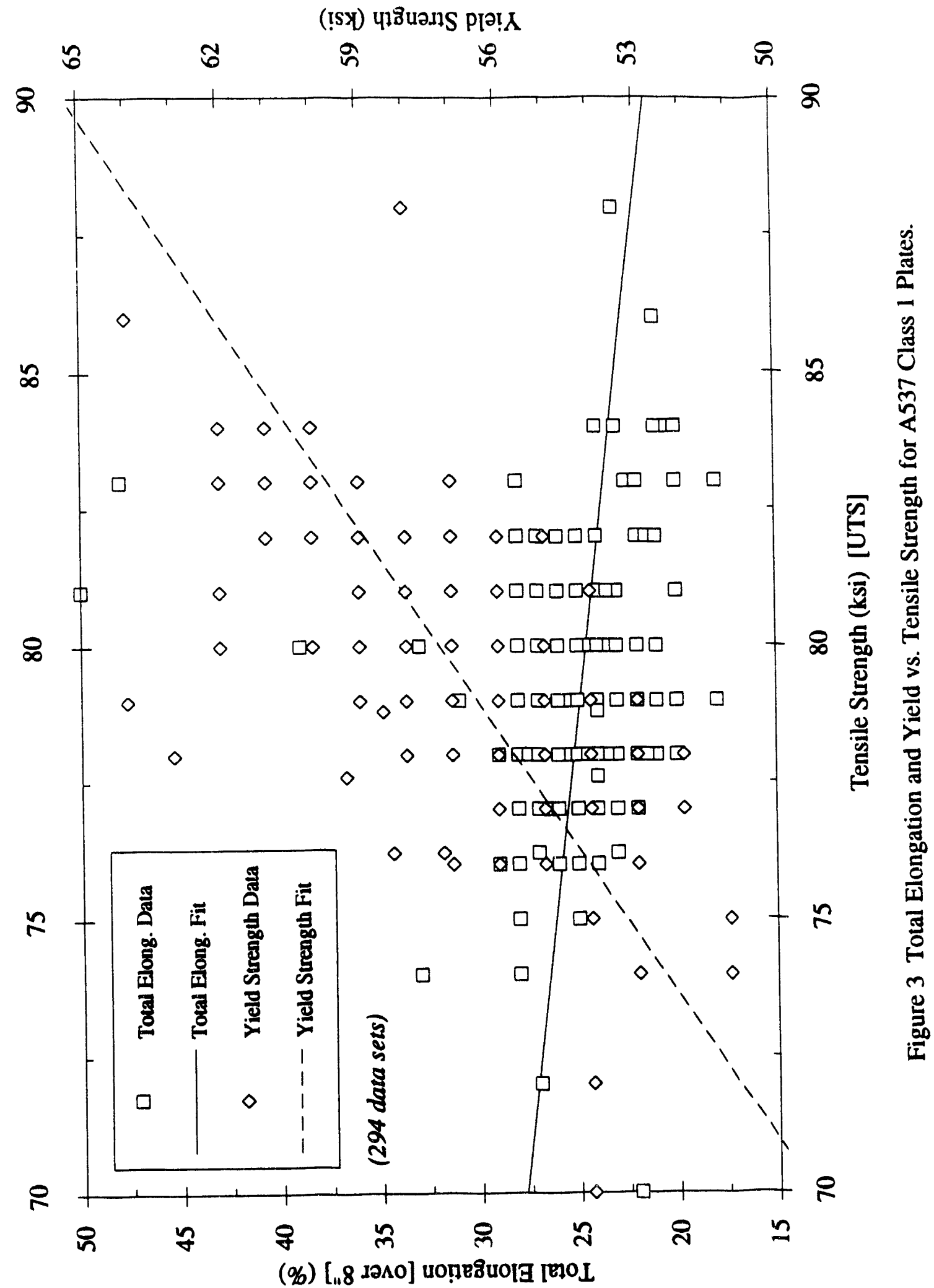




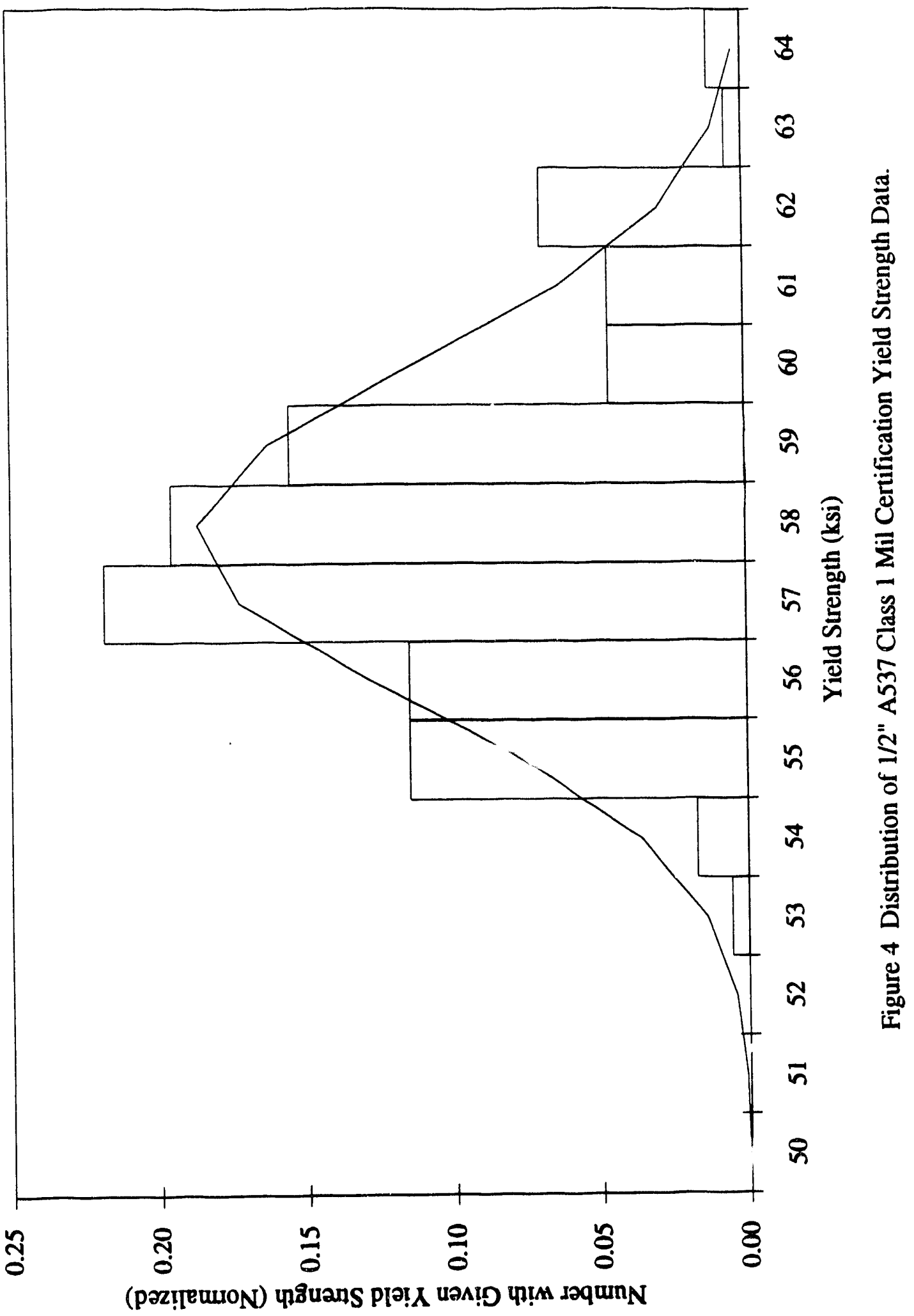




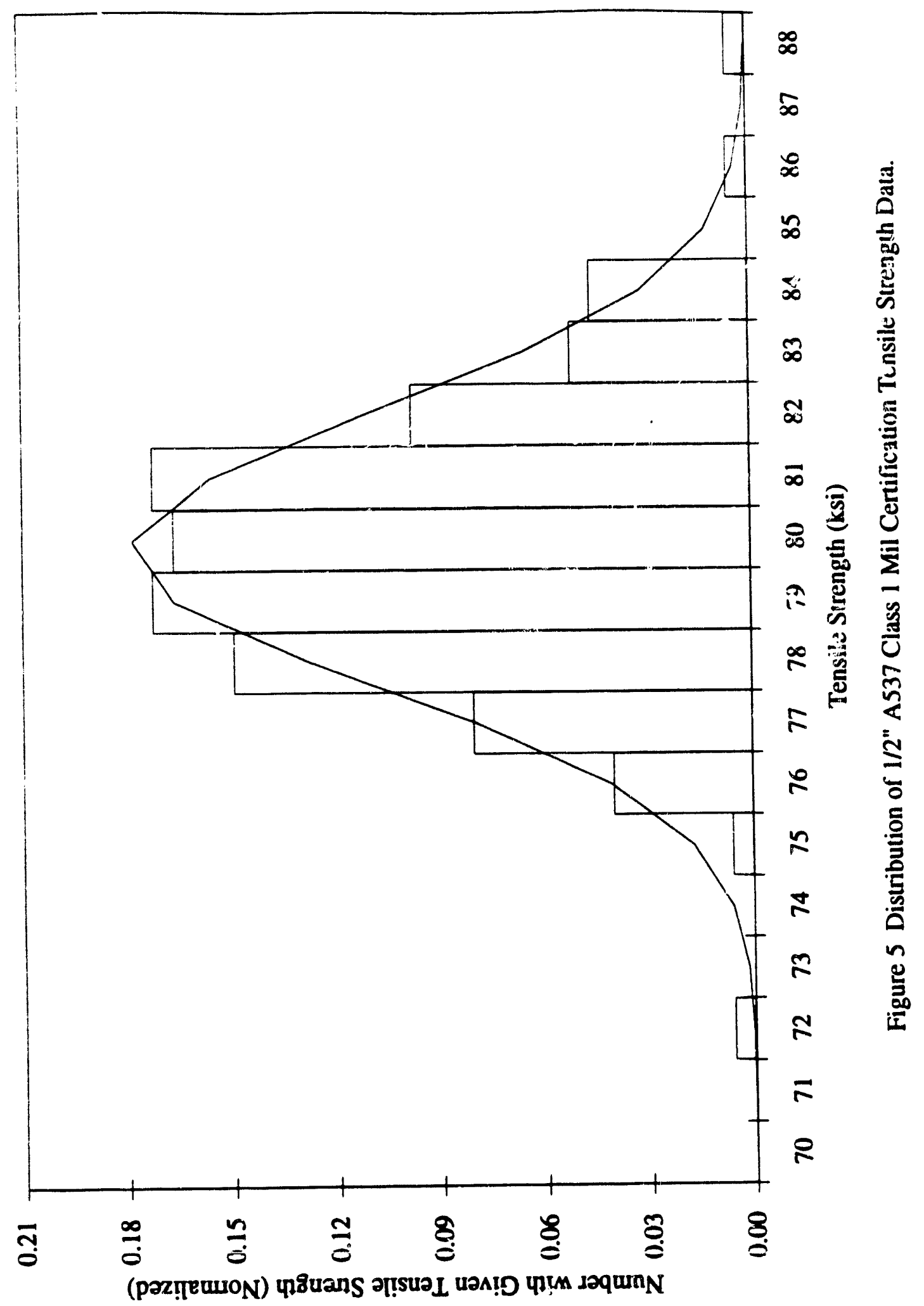




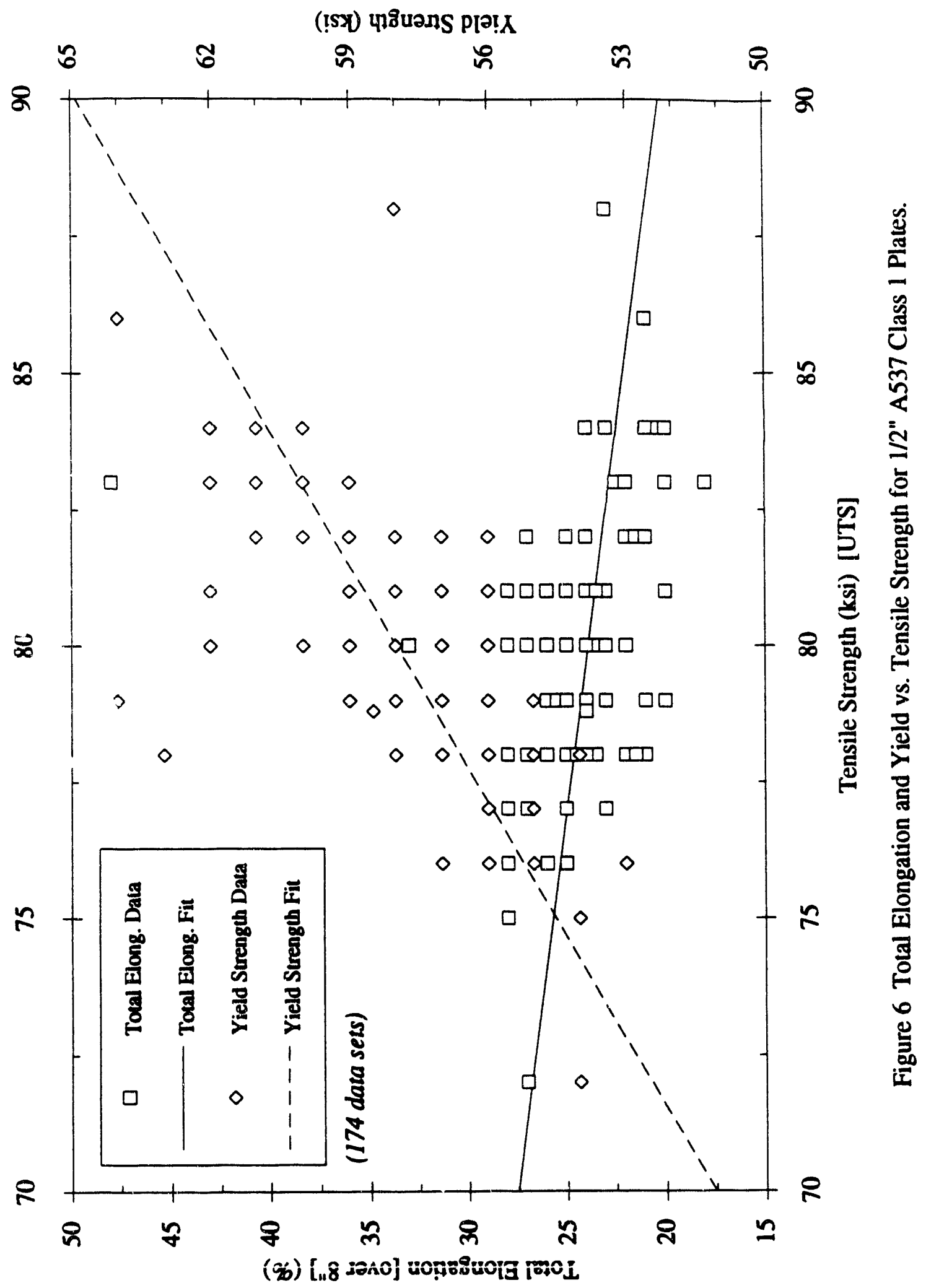




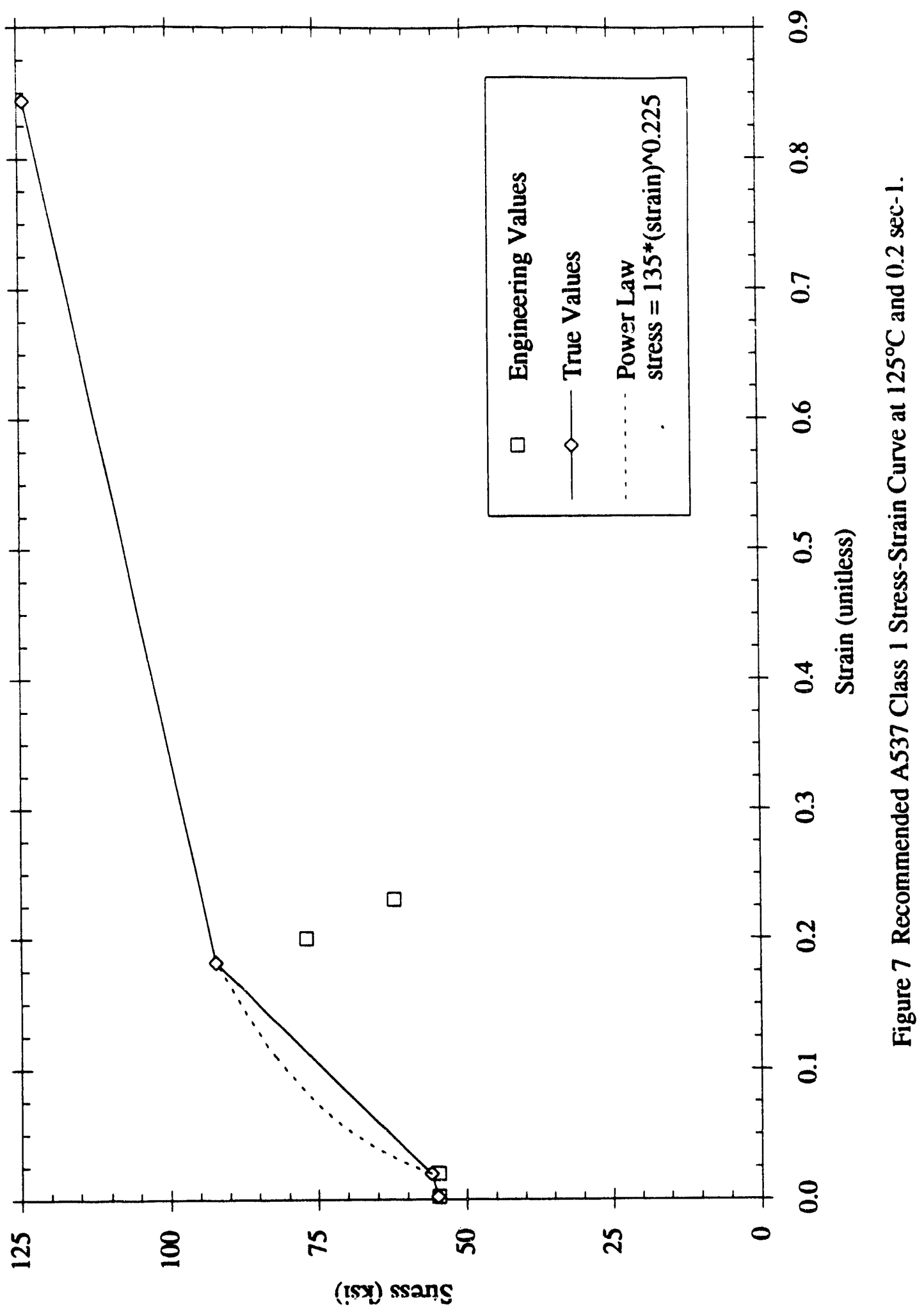




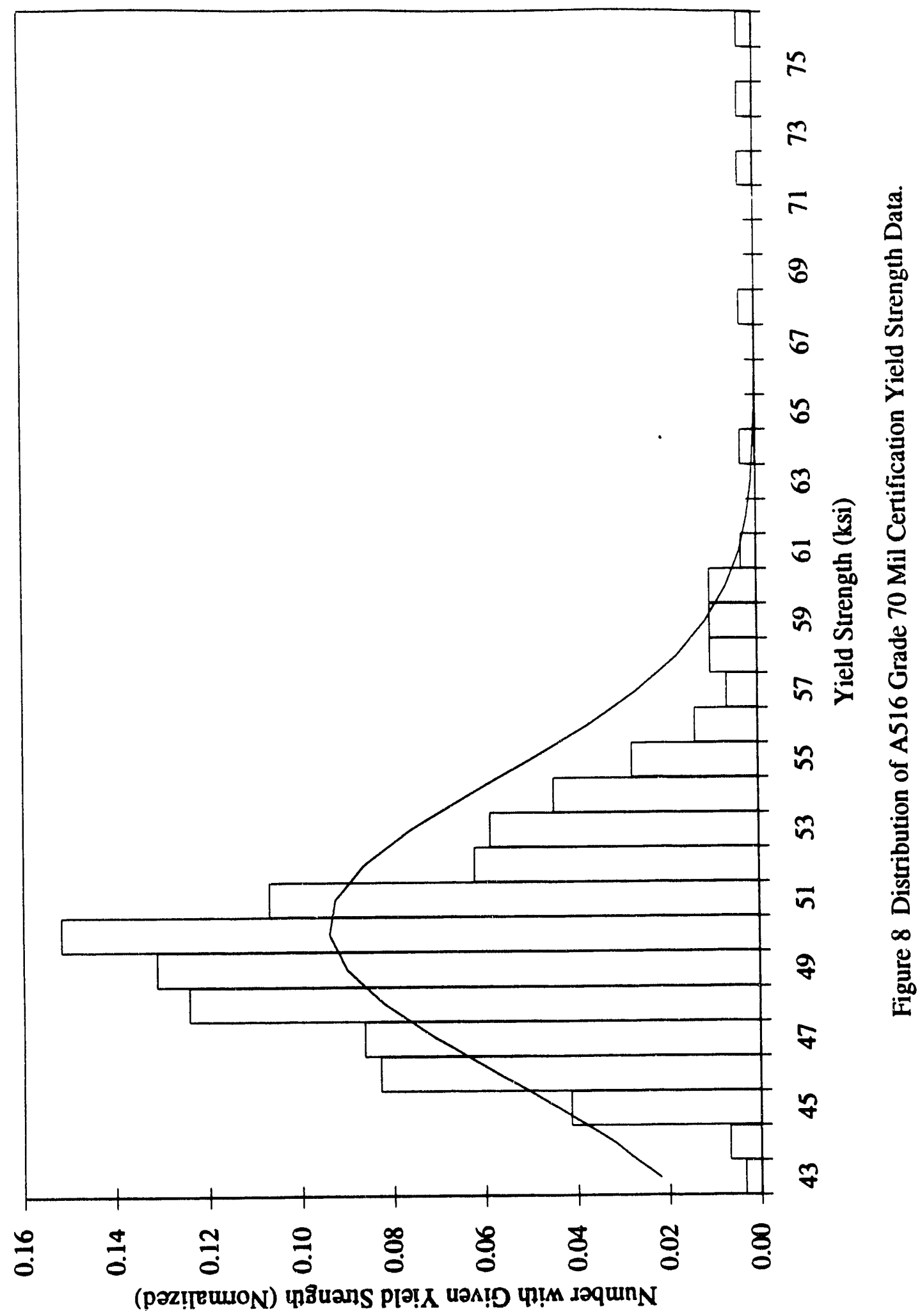




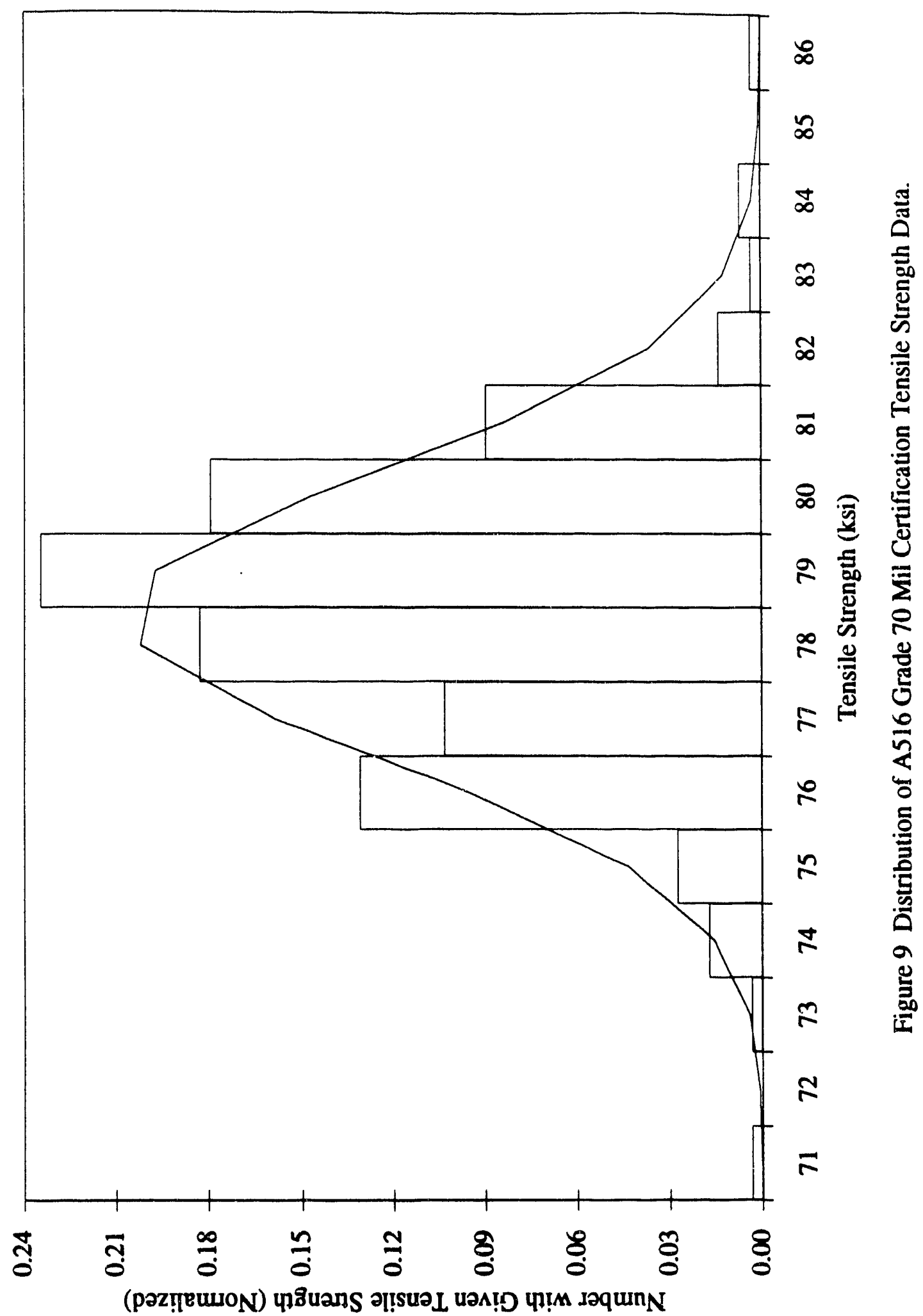




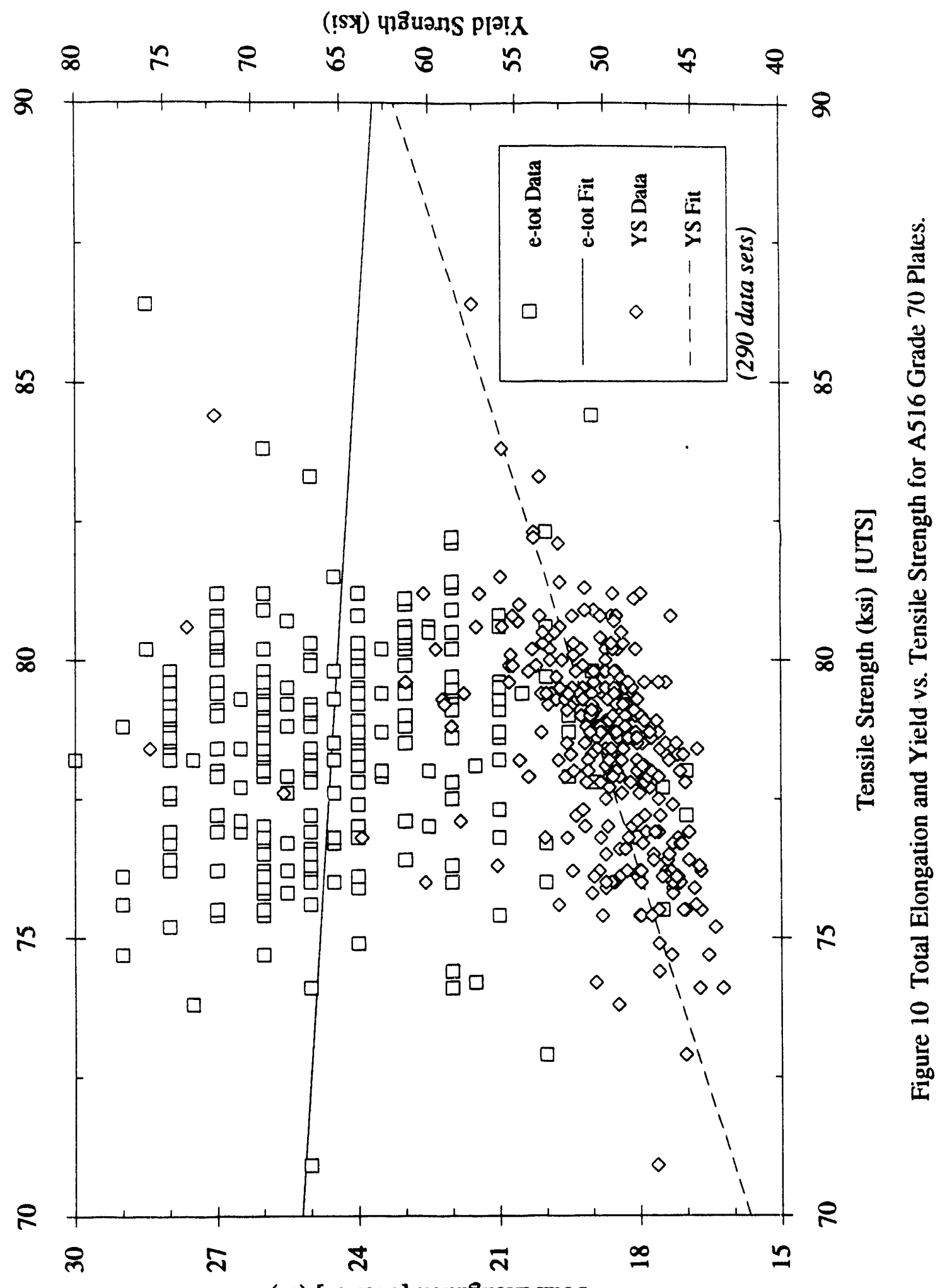

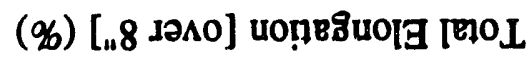




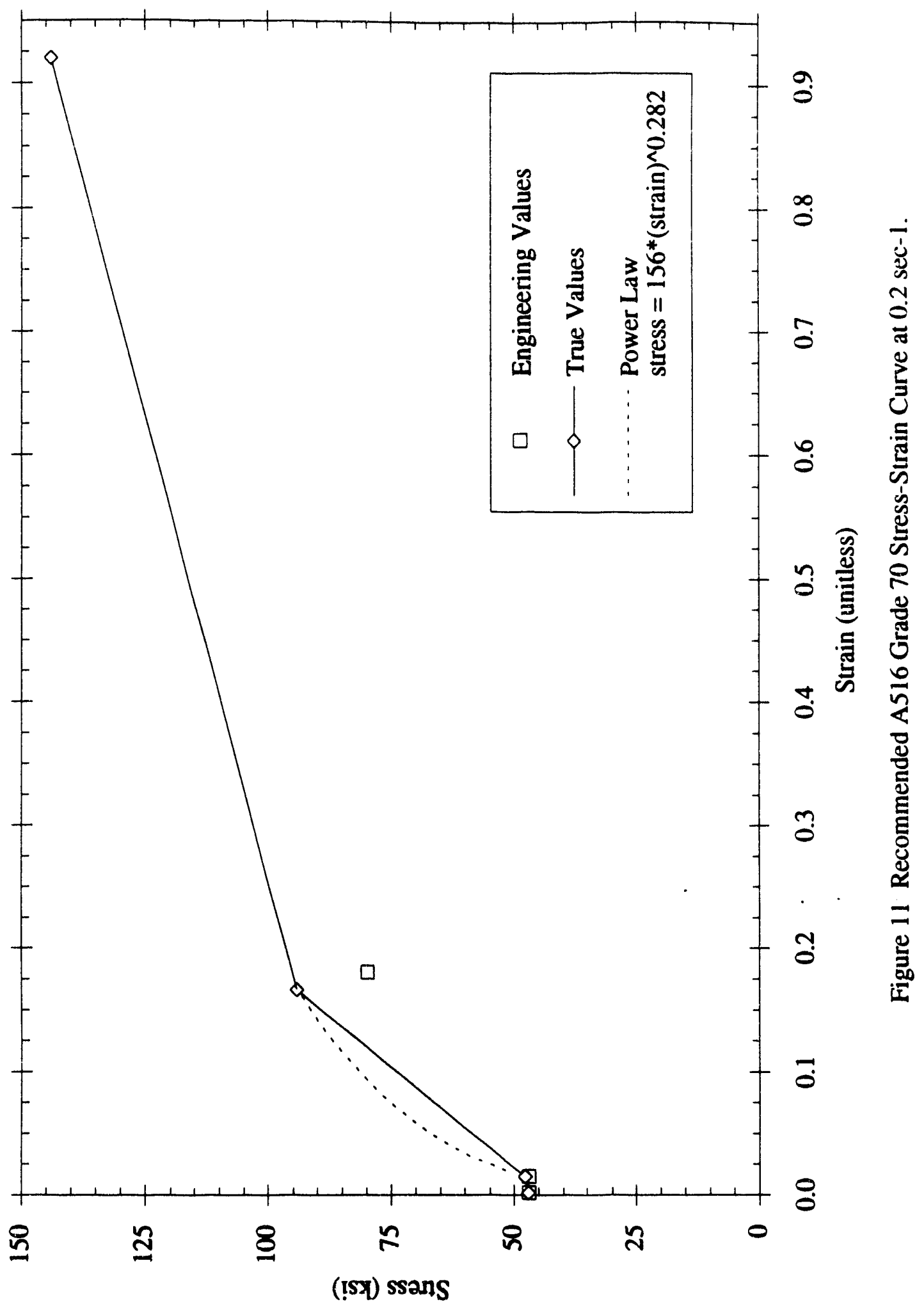



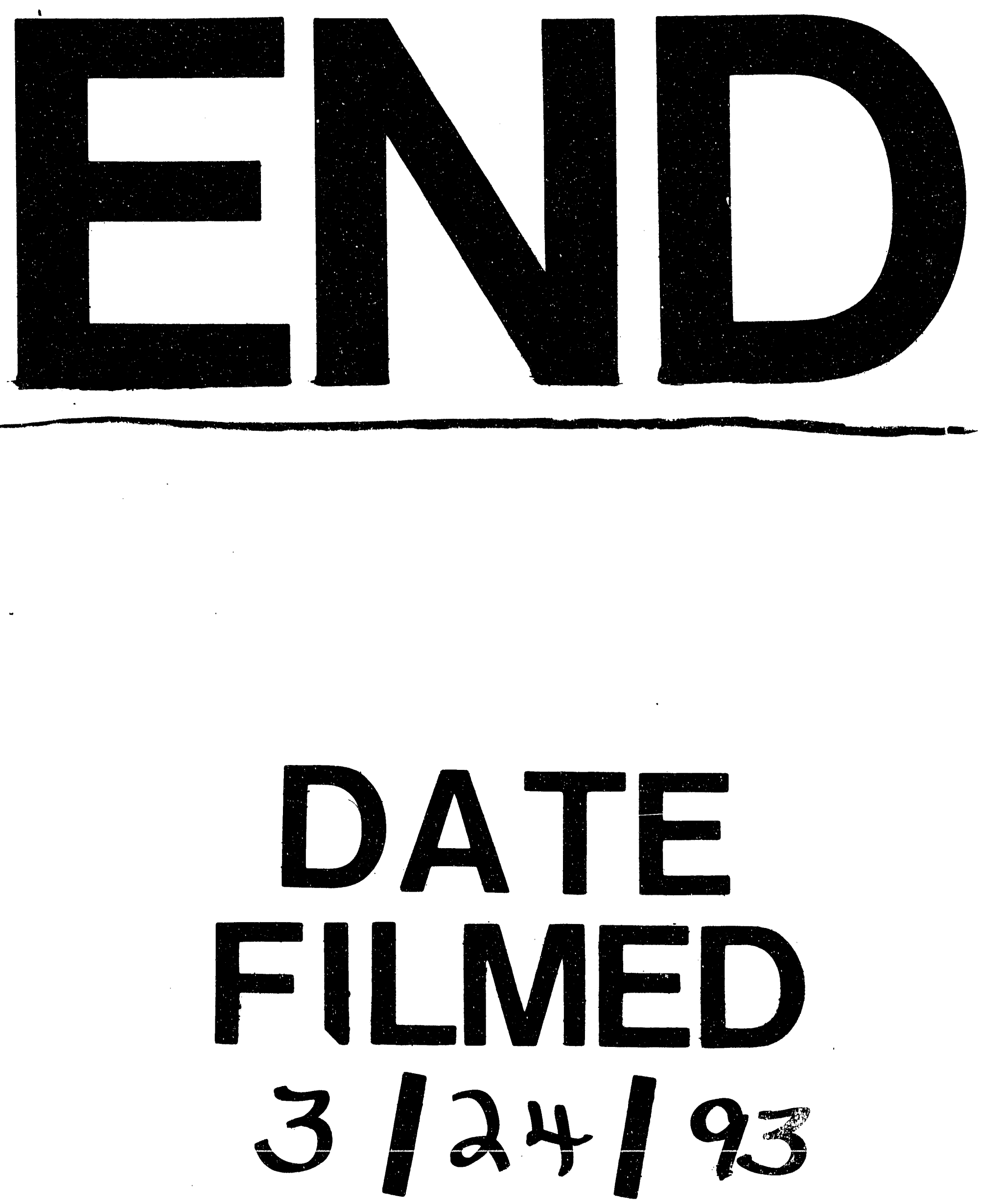


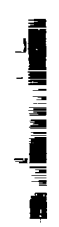

